\title{
Chromium Pollution in European Water, Sources, Health Risk, and Remediation Strategies: An Overview
}

\author{
Marina Tumolo ${ }^{1,2}{ }^{(}$, Valeria Ancona ${ }^{1, *}$, Domenico De Paola ${ }^{3}\left({ }^{\circ}\right.$, Daniela Losacco ${ }^{1,2}$, \\ Claudia Campanale ${ }^{1}$ (D) Carmine Massarelli ${ }^{1}$ (D) and Vito Felice Uricchio ${ }^{1}$ (D) \\ 1 Water Research, Institute-Italian National Research Council (IRSA-CNR), 70132 Bari, Italy; \\ marina.tumolo@ba.irsa.cnr.it (M.T.); daniela.losacco@ba.irsa.cnr.it (D.L.); \\ claudia.campanale@ba.irsa.cnr.it (C.C.); carmine.massarelli@ba.irsa.cnr.it (C.M.); \\ vito.uricchio@ba.irsa.cnr.it (V.F.U.) \\ 2 Department of Biology, University of Bari, 70126 Bari, Italy \\ 3 Institute of Biosciences and Bioresources, Italian National Research Council (IBBR-CNR), 70126 Bari, Italy; \\ domenico.depaola@ibbr.cnr.it \\ * Correspondence: ancona@irsa.cnr.it
}

Received: 26 June 2020; Accepted: 24 July 2020; Published: 28 July 2020

\begin{abstract}
Chromium is a potentially toxic metal occurring in water and groundwater as a result of natural and anthropogenic sources. Microbial interaction with mafic and ultramafic rocks together with geogenic processes release $\mathrm{Cr}$ (VI) in natural environment by chromite oxidation. Moreover, $\mathrm{Cr}$ (VI) pollution is largely related to several Cr (VI) industrial applications in the field of energy production, manufacturing of metals and chemicals, and subsequent waste and wastewater management. Chromium discharge in European Union (EU) waters is subjected to nationwide recommendations, which vary depending on the type of industry and receiving water body. Once in water, chromium mainly occurs in two oxidation states $\mathrm{Cr}$ (III) and $\mathrm{Cr}$ (VI) and related ion forms depending on $\mathrm{pH}$ values, redox potential, and presence of natural reducing agents. Public concerns with chromium are primarily related to hexavalent compounds owing to their toxic effects on humans, animals, plants, and microorganisms. Risks for human health range from skin irritation to DNA damages and cancer development, depending on dose, exposure level, and duration. Remediation strategies commonly used for Cr (VI) removal include physico-chemical and biological methods. This work critically presents their advantages and disadvantages, suggesting a site-specific and accurate evaluation for choosing the best available recovering technology.
\end{abstract}

Keywords: chromium; pollution; health risk; remediation

\section{Introduction}

Chromium is a transition metal that exhibits a complex chemistry. In water, chromium exists with oxidation states ranging from +6 to -2 . The most stable forms are the hexavalent $\mathrm{Cr}$ (VI) and trivalent $\mathrm{Cr}$ (III) ones and can interconvert with each other [1]. Depending on the solution pH values, chromium can be encountered mainly as $\mathrm{Cr}$ (III) or $\mathrm{Cr}$ (VI) [2]. In nature, the oxidation of $\mathrm{Cr}$ (III) is not favoured because of the high $\mathrm{E}^{\circ}$ value of the $\mathrm{Cr}$ (III)/Cr (VI) redox couple, only manganese oxide seems to be an effective oxidant in the environment. Otherwise, $\mathrm{Cr}$ (VI) can be easily reduced to $\mathrm{Cr}$ (III) by different reducing agents including Fe (II), phosphate, sulphide, and organic matter, for example, humic acid [3-5].

Public concerns with chromium are primarily related to hexavalent compounds owing to their toxic effects on humans, animals, plants, and microorganisms [6]. The risks for human health are 
dependent on dose, exposure level, and duration. A lasting and continuative exposure to chromium even at low concentration, that is, in the case of occupational exposure, can damage the skin, eyes, blood, respiratory, and immune system $[7,8]$. On a cellular level, the genotoxic effect of chromium leads to oxidative stress, DNA damages, and other harms that can result in tumour development $[9,10]$.

Environmental contamination of $\mathrm{Cr}(\mathrm{VI})$ is gaining more consideration because it is widespread throughout the world with high levels in water and soil owing to natural and anthropogenic activities [11-13]. These include mining and metal works, steel and metal alloys production, paint manufacturing, wood and paper processing, dyeing, and raising the chromium content in wastewater [14-16]. In addition, the fall out of ashes produced by the incineration of coal or municipal waste for energy generation and the production of second-generation fertilizers contribute to the elevated Cr (VI) content in soil and water [17].

Chromium discharge limits in water are regulated on a national scale and often vary depending on the different type of industry or receiving water body (marine water, lake, river, sewer system). In Europe, the admissible concentration values of $\mathrm{Cr}(\mathrm{VI})$ as $\mathrm{mg} \mathrm{L}^{-1}$ range from 0.05 to 2 according to the environmental policy of Norway and Poland (most precautionary value) and Netherlands $[18,19]$.

Traditional approaches for $\mathrm{Cr}(\mathrm{VI})$ removal from water and wastewaters include physico-chemical methods such as chemical reduction, adsorption on porous surfaces with sites for ion exchange, and electrocoagulation. These strategies are also highly efficient for a high content of $\mathrm{Cr}$ (VI), but some limitations are related to sludge production, large amount of chemicals required, and consequent risk of secondary pollution [20]. To overcome these issues, bioremediation can represent a valid alternative, particularly with lower and moderate concentrations of $\mathrm{Cr}(\mathrm{VI})$ present in large volumes of wastewater [21-23]. Bioremediation techniques generally take advantage of the metabolisms of microbes, particularly bacteria, thanks to their high plasticity and widespread presence [24]. Bioremediation processes require bacterial resistance to pollutant and include intracellular and extracellular bioreduction, biosorption on cellular surface, and bioaccumulation.

This review intends to provide an overview on chromium pollution in European Union (EU) waters at present, describing in detail its sources and health risks. This work also critically highlights the advantages and disadvantages of the main physico-chemical and biological techniques for $\mathrm{Cr}(\mathrm{VI})$ removal, developed in the last decade.

\section{Chromium in the Environment: Natural Occurrence and Anthropogenic Source}

Chromium exists in the environment in a number of valence states, whose most stable forms, $\mathrm{Cr}$ (VI) and $\mathrm{Cr}$ (III), are characterized by different properties [25]. The main source of $\mathrm{Cr}$ (III) in the environment is a natural one and it is related to chromite ore $\left(\mathrm{FeCr}_{2} \mathrm{O}_{4}\right)[1,26]$. This mineral present in mafic and ultramafic rocks is a complex of magnesium, iron, aluminium, and chromium in varying proportions, depending on the deposit [27-31].

Chromite in ultramafic rocks typically occurs as stratiform deposits, which may vary from less than a centimetre to $5-8 \mathrm{~m}$. A secondary type of chromite deposit is known as podiform deposit, consisting of irregular pods or veinlets of aggregated chromite, often with nodular or orbicular textures [31]. Generally, chromite is chemically inert and insoluble in water, but microbial interventions together with other geochemical processes could promote the $\mathrm{Cr}$ (III) release in nature from chromite, increasing the possibility of its oxidation to $\mathrm{Cr}$ (VI) [26].

Chromite represents the main commercial form of chromium for industrial application. At industrial level the process involved in the $\mathrm{Cr}$ (VI) extraction from chromite has been known since the 19 th century as oxidative roasting $[26,28,30]$. In the environment kinetic and several other factors, that is, $\mathrm{pH}$ and organic matter, mean that $\mathrm{Cr}$ (III) species dominate in nature. However, levels of $\mathrm{Cr}(\mathrm{VI})$ exceeding $70-90 \mu \mathrm{g} \mathrm{L}^{-1}$ in groundwater and water have been frequently measured as a result of man-made pollution $[19,32,33]$. Industrial use and urban source in fact are closely related to $\mathrm{Cr}$ (VI) accumulation in sediments and waters [34]. For example, the improper disposal of chromite ore processing residues, that is stocking them in open dump sites, results in a rapid migration by 
leaching of soluble contaminants into surface waters and groundwater [33,35]. The residue material is a mixture of finer particulate waste matter and fused material. The latter is finely porous with exposed chromite particles on the outer and inner surfaces, which tend to leach from all exposed surfaces [36]. Moreover, phosphate amendments produced from sewage sludge ashes or tannery sludge are rich in hexavalent chromium which can be leached. Their improper use is the main cause of chromium pollution in agricultural areas $[37,38]$.

Although to a lesser extent than human activities, some geogenic processes also have an impact on the soil and groundwater Cr (VI) content [39], such as the weathering of ultramafic igneous and metamorphic rocks in several European countries (Greece, Italy, France, Serbia and Poland) [32,40]. For example groundwaters proximal to ultramafic rocks and sediments in La Spezia province, Italy, have a $\mathrm{Cr}(\mathrm{VI})$ content ranging from 5 to $73 \mu \mathrm{g} \mathrm{L}-1$ exceeding the Italian limit for drinking water set at $5 \mu \mathrm{g} \mathrm{L}^{-1}$ as well as the World Health Organization limit for drinking water of $50 \mu \mathrm{g} \mathrm{L}^{-1}$ [32,41]. Birnessite is a Mn (IV) oxide-containing mineral, which commonly forms a coat onto weathered grains and fractures in Cr-rich ultramafic rocks. This mineral is associated with the $\mathrm{Cr}$ (VI) formation from natural $\mathrm{Cr}$ (III) in the environment [41,42]. Other Mn (IV) minerals involved in Cr (III) oxidation are asbolane, lithiophorite, hausmannite, and manganite. Particularly, in the last two minerals, the Mn (IV) reduction provides the most free energy for $\mathrm{Cr}$ (III) oxidation [43].

In the light of the above, hexavalent chromium concentration in groundwaters represents a combination of natural and anthropogenic factors, which are difficult to distinguish. They are summarized in Figure 1.

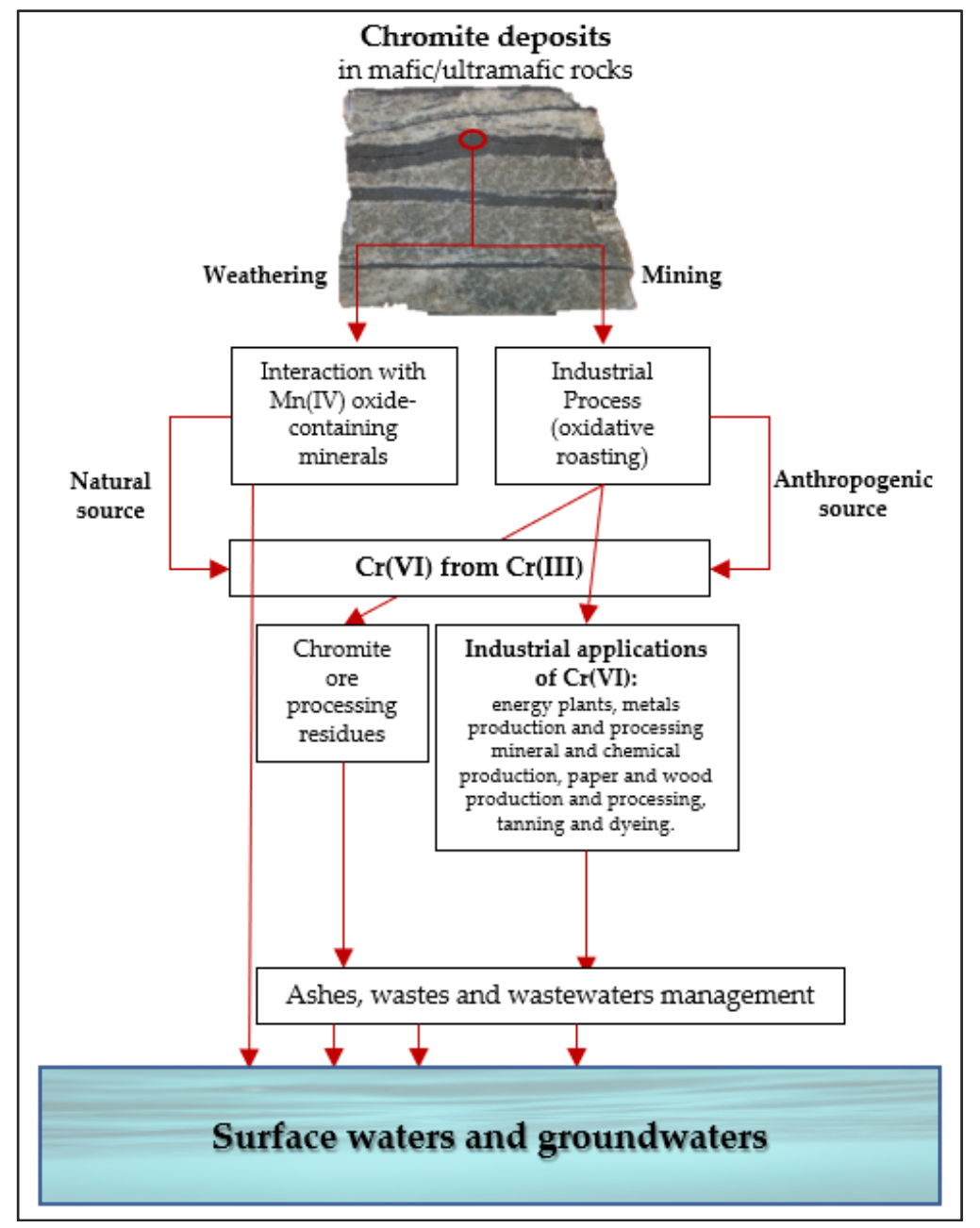

Figure 1. Schematic representation of the main sources of $\mathrm{Cr}(\mathrm{VI})$ in waters and groundwaters. 
According to the latest update of the European Pollutant Release register, a total of 512 facilities from EU countries are registered as they release chromium compounds into air and water [28,44]. These facilities mainly belong to the energy sector, including thermal power stations and mineral oil and gas refineries (on average, 27-80 $\mathrm{mg}$ per $\mathrm{kg}$ of oily sludge) [45]. Other industries are related to waste and wastewater management, metal production and processing (including metal ore, pig iron and steel), mineral and chemical production, paper and wood production and processing, tanning and dyeing [17,32,44,46-49]. The percentage contribution of the EU industries for Cr emissions in water is shown in Figure 2. Thermal power stations and other combustion installations contribute the most, followed by waste and wastewater management. Particularly, ashes generated as a waste material through combustion processes of coal, lignite, and municipal solid waste are rich in hexavalent chromium [39,50-53].

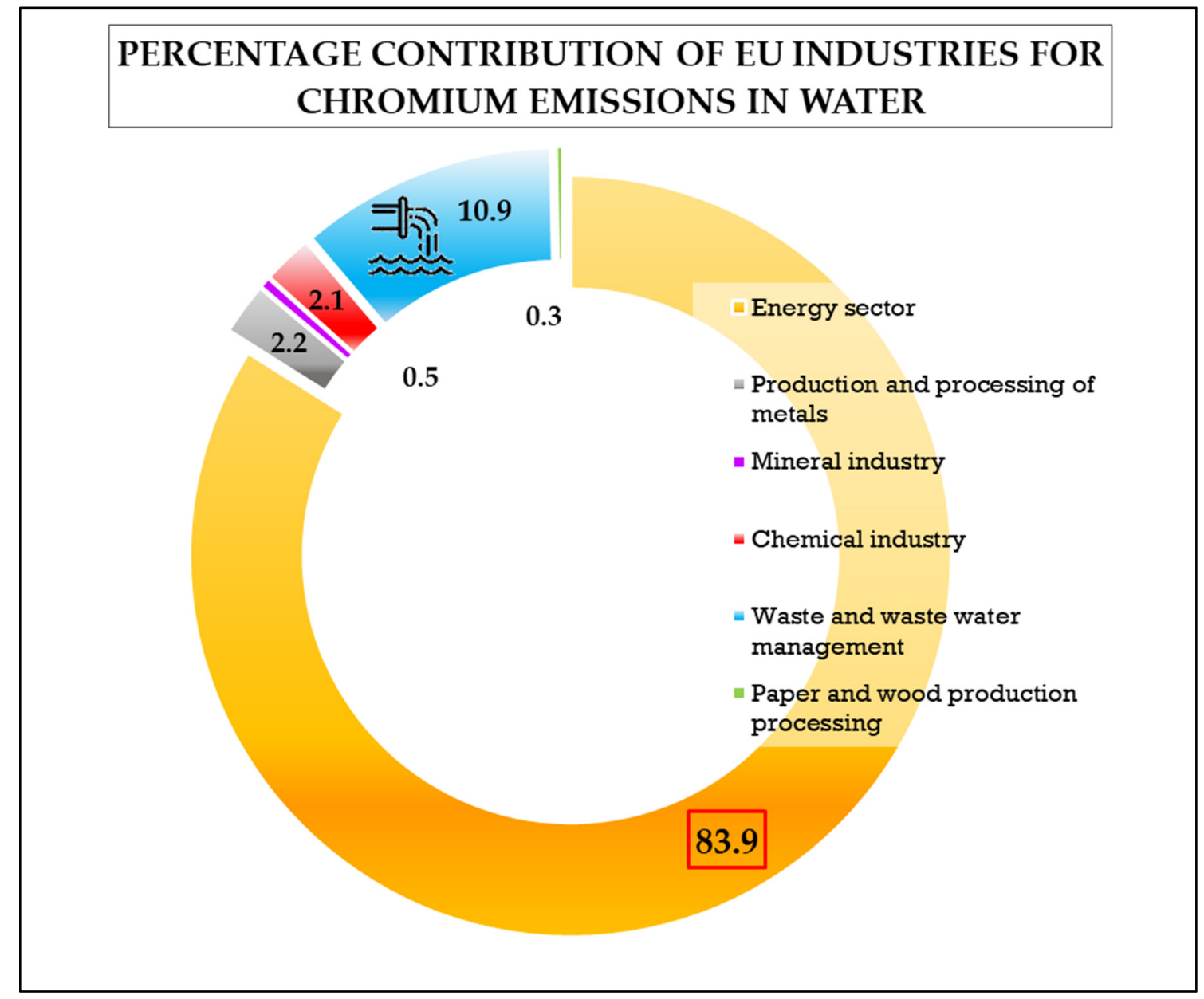

Figure 2. Percentage of $\mathrm{Cr}$ emission in EU waters per industrial sector. Data released by the European Environmental Agency are related to the year 2017 (data source: [44]).

With regards to the tons of chromium and its compounds released in EU waters per industrial activity per year, see Table A1 of Appendix A.

\section{Chromium Emissions and Discharge Limits for EU Member States}

The European Directives 2000/60/EC and 2008/105/EC in the field of water policy and their subsequent amendments (Directive 2013/39/EU) did not identify chromium as a priority substance with regard to hazardous substances. Otherwise, chromium was listed in the Annex VIII of the Water Framework Directive as a main pollutant [54]. To date, no discharge limit has been established by the EU. Each Member State regulates chromium emission in the aquatic environment and national discharge 
limits often vary, according to the industrial type and the receiving water body [18]. Some governments regulate differently the concentration of total $\mathrm{Cr}$ from $\mathrm{Cr}(\mathrm{VI})$ supported by chemical, ecotoxicological, and epidemiological evidence [34,55-57]. In other countries, such as Greece, Austria, and Denmark, environmental policies regulate only the concentration of total chromium in water, according to studies that report a very high correlation between total chromium and the fraction of Cr (VI) [32,58]. The maximum discharge limits are $2 \mathrm{mg} \mathrm{L}^{-1}$ for $\mathrm{Cr}$ (VI) and $5 \mathrm{mg} \mathrm{L}^{-1}$ for total $\mathrm{Cr}$ in EU Member States, according to the policies of Netherlands and Spain and Belgium, respectively [18]. Particularly, the value of $2 \mathrm{mg} \mathrm{L}^{-1}$ for $\mathrm{Cr}$ (VI) in Netherlands refers to the discharge of wastewaters from paint and ink producing facilities. National discharge limits in water for most European countries are listed in Table 1.

Table 1. National discharge limits for total $\mathrm{Cr}$ and $\mathrm{Cr}(\mathrm{VI})$ concentrations in wastewaters, expressed as $\mathrm{mg} \mathrm{L}^{-1}$ (adapted from [18]).

\begin{tabular}{|c|c|c|c|c|c|c|}
\hline Member State & Austria ${ }^{1}$ & Belgium $^{1,2,3}$ & Croatia $^{3}$ & Cyprus $^{4}$ & Czech Republic ${ }^{1,2}$ & Denmark $^{3}$ \\
\hline Total Cr & $0.5-3$ & $0.5-5$ & $1-4$ & 0.5 & $0.5-1$ & $0.001-0.3$ \\
\hline $\mathrm{Cr}(\mathrm{VI})$ & - & $0.1-1$ & 0.1 & 0.1 & $0.1-0.3$ & - \\
\hline Total Cr & 0.5 & 0.7 & 0.5 & $0.1-0.5$ & $0.6-1.5$ & $0.2-1$ \\
\hline $\mathrm{Cr}(\mathrm{VI})$ & 0.1 & 0.2 & 0.1 & $0.05-0.5$ & - & $0.1-0.5$ \\
\hline Total Cr & 0.5 & $2-4$ & - & 0.5 & 0.5 & 0.5 \\
\hline $\mathrm{Cr}(\mathrm{VI})$ & 0.1 & 0.2 & $0.1-0.2$ & 0.1 & 0.1 & $0.1-2$ \\
\hline Member State & Norway & Poland $^{1}$ & Portugal & Sweden ${ }^{4}$ & Slovak Republic ${ }^{1}$ & Slovenia $^{1}$ \\
\hline Total Cr & - & - & 2 & 0.5 & $0.5-1$ & $0.5-1$ \\
\hline $\mathrm{Cr}(\mathrm{VI})$ & 0.05 & $0.05-0.5$ & 0.1 & 0.1 & 0.1 & 0.1 \\
\hline
\end{tabular}

Data related to the Cr emission trend between 1990 and 2017 by EU countries, published by the European Environmental Agency (EEA), revealed a remarkable decreasing trend (-71\%). On the other hand, a weak increase was measured in 2017 (+1.6\%), with Germany, Poland, Italy, and the United Kingdom as major contributors for $\mathrm{Cr}$ emissions (23\%, 11.4\%, 10.8\%, and 10\% respectively, with regards to the total) [59]. It should be noted that, since February 2020, the United Kingdom is no longer an EU Member State.

\section{Chromium Prevalent Forms in Aqueous Environment}

Among the potentially toxic trace elements, chromium is the most common pollutant in groundwaters [60-62]. Chromium speciation in water depends on several factors, including organic matter, red-ox conditions and $\mathrm{pH}$ levels [55]. In general higher $\mathrm{pH}$ values favour the oxidation while lower $\mathrm{pH}$ values favour reduction [26,63].

The main free aqueous forms of $\mathrm{Cr}$ (III) are $[\mathrm{Cr}(\mathrm{OH})]^{2+},\left[\mathrm{Cr}(\mathrm{OH})_{2}\right]^{+}, \mathrm{Cr}(\mathrm{OH})_{3}$ (aq) and $\left[\mathrm{Cr}(\mathrm{OH})_{4}\right][1,3,34,64]$. These ions can confer green colour to water. In natural groundwater $\mathrm{pH}$ ranging from 6 to 8 and $\left[\mathrm{Cr}(\mathrm{OH})_{2}\right]^{+}$prevails; under slightly acidic to alkaline conditions $\mathrm{Cr}$ (III) can quickly precipitate as amorphous chromium hydroxide, $\mathrm{Cr}(\mathrm{OH})_{3}$ (s) [1].

Compared to $\mathrm{Cr}$ (III), aqueous hexavalent chromium, $\mathrm{Cr}$ (VI), is the most oxidized, mobile, reactive, and toxic form with no sorption in most sediment at $\mathrm{pH}>7$. While acidity and other factors which increase the positive charge on soil colloids determine $\mathrm{Cr}$ (VI) adsorption and its removal from the liquid phase [64]. Adsorption of $\mathrm{Cr}$ (VI) usually decreases while $\mathrm{pH}$ increasing. $\mathrm{Cr}$ (VI) exists in solution as monomeric species $\mathrm{H}_{2} \mathrm{CrO}_{4},\left[\mathrm{HCrO}_{4}\right]^{-}$(hydrogen chromate) and $\left[\mathrm{CrO}_{4}\right]^{2-}$ (chromate) which gives 
a yellow colour to water when $\mathrm{Cr}(\mathrm{VI})$ concentration is greater than $1 \mu \mathrm{g} \mathrm{L}^{-1}$. The monovalent form predominates in acidic water while the divalent form predominates at neutral $\mathrm{pH}$ or above. In very acidic solution hexavalent chromium also exists as the dimeric ion $\left[\mathrm{Cr}_{2} \mathrm{O}_{7}\right]^{2-}$ (dichromate) $[1,65,66]$. Normal environmental conditions favour the reduction of $\mathrm{Cr}$ (VI) to $\mathrm{Cr}$ (III) rather than the oxidation of $\mathrm{Cr}$ (III) to $\mathrm{Cr}$ (VI). Although $\mathrm{Cr}$ (VI) is thermodynamically stable only under oxidising conditions [67], the kinetics of reduction to $\mathrm{Cr}$ (III) under certain conditions can be slow [19]. Organic compound containing sulfhydryl groups and ferrous ions are common reductants, while the inorganic materials mostly involved into the natural oxidation of trivalent chromium in the hexavalent form are the manganese oxides [1,3]. Main forms of chromium in aquatic environments are listed in Table 2.

Table 2. Chromium oxidation states and main forms in aquatic environments.

\begin{tabular}{|c|c|c|c|}
\hline Oxidation State & Form & pH Condition & References \\
\hline \multirow[t]{5}{*}{ Cr (III) } & $\begin{array}{l}\text { Hexacoordinate complexes with complexing agents } \\
\text { (i.e., water, ammonia, sulphate, urea, and organic acid) }\end{array}$ & $0<\mathrm{pH}<4$ & [2] \\
\hline & $\mathrm{Cr}\left(\mathrm{H}_{2} \mathrm{O}\right)_{5}(\mathrm{OH})^{2+}$ abbreviated as $[\mathrm{Cr}(\mathrm{OH})]^{2+}$ & $\begin{array}{l}\text { slightly acidic conditions, } \\
3.8<\mathrm{pH}<6.3\end{array}$ & {$[3,68,69]$} \\
\hline & {$\left[\mathrm{Cr}\left(\mathrm{H}_{2} \mathrm{O}\right)_{4}(\mathrm{OH})_{2}\right]^{+}$abbreviated as $\left[\mathrm{Cr}(\mathrm{OH})_{2}\right]^{+}$} & $6<\mathrm{pH}<8$ & {$[68,69]$} \\
\hline & $\mathrm{Cr}(\mathrm{OH})_{3}(\mathrm{aq})^{*}$ & $\begin{array}{l}\text { slightly acidic to alkaline } \\
\text { conditions }\end{array}$ & \\
\hline & $\mathrm{Cr}(\mathrm{OH})_{3}(\mathrm{~s})$ & $\begin{array}{c}6.4<\mathrm{pH}<11.5 ; \text { max at } \\
\mathrm{pH} \approx 8\end{array}$ & {$[1,66,69,70]$} \\
\hline \multirow{5}{*}{$\mathrm{Cr}(\mathrm{VI})$} & {$\left[\mathrm{Cr}(\mathrm{OH})_{4}\right]^{-}$} & $\mathrm{pH}>11.5$ & [3] \\
\hline & $\mathrm{H}_{2} \mathrm{CrO}_{4}$ & $\mathrm{pH}<1$ & [66] \\
\hline & {$\left[\mathrm{HCrO}_{4}\right]^{-}$} & $1<\mathrm{pH}<6.4$ & {$[1,26,66,69]$} \\
\hline & {$\left[\mathrm{CrO}_{4}\right]^{2-}$} & $\mathrm{pH} \geq 6.4$ & {$[1,26,66,69]$} \\
\hline & {$\left[\mathrm{Cr}_{2} \mathrm{O}_{7}\right]^{2-}$} & $\mathrm{pH}<3$ & [66] \\
\hline
\end{tabular}

* sparingly soluble form, which tends to precipitate quickly.

\section{Determination of Environmental Chromium}

In recent years, techniques capable of determining total chromium and its oxidation states have been improved in order to optimize the detection limit and minimize the interconversion between $\mathrm{Cr}$ (III) and $\mathrm{Cr}$ (VI) which can occur during analytical procedures [55].

The analysis of total chromium means quantify the presence of $\mathrm{Cr}(\mathrm{III})$ and $\mathrm{Cr}(\mathrm{VI})$ in the dissolved and suspended fractions of a water sample. The analysis of total dissolved chromium is determined after filtration and preservation with nitric acid to a $\mathrm{pH}$ level below 2.0 to minimize precipitation [71]. Moreover, the determination of both dissolved and suspended fractions requires sample acidification to dissolve the suspended fractions. The acid digestion is necessary when the turbidity of the acid-preserved sample is higher than one nephelometric turbidity unit (NTU). After the digestion procedure, the sample is analyzed using several analytical methods such as atomic absorption spectroscopy (AAS), graphite furnace atomic absorption spectrometry (GFAAS) [72], inductively coupled plasma mass spectrometry (ICP-MS) [73-75], inductively coupled plasma atomic emission spectroscopy (ICP-AES) [76].

$\mathrm{Cr}$ (VI) can be determined in filtered solutions by colorimetric reaction with 1,5 diphenylcarbazide (DPC) at the wavelength of $540 \mathrm{~nm}[22,77]$. Despite its simplicity, the method that uses DPC suffers from the presence of several interferents that can bring to an overestimation or underestimation of the values of $\mathrm{Cr}$ (VI), such as Fe (III), Fe (II), Hg, V, sulphides sulphates and organic matter present in the matrix [2]. In the EPA Method 218.7 ion chromatography followed by derivatization with 1,5-diphenylcarbazide and UV-VIS analysis is used for the detection of $\mathrm{Cr}$ (VI) in drinking water [78].

Other Methods using high-performance liquid chromatography (HPLC) coupled to ICP-MS have also been adopted for the quantification of both of $\mathrm{Cr}$ (III) and $\mathrm{Cr}$ (VI) in water samples [79].

The most used analytical techniques for chromium determination in water samples are listed in Table 3. 
Table 3. Analytical methods for total $\mathrm{Cr}, \mathrm{Cr}$ (III), and $\mathrm{Cr}$ (VI) in water samples. AAS, atomic absorption spectroscopy; GFAAS, graphite furnace atomic absorption spectrometry; ICP-MS; inductively coupled plasma mass spectrometry; ICP-AES, inductively coupled plasma atomic emission spectroscopy; HPLC, high-performance liquid chromatography; DPC, 1,5 diphenylcarbazide.

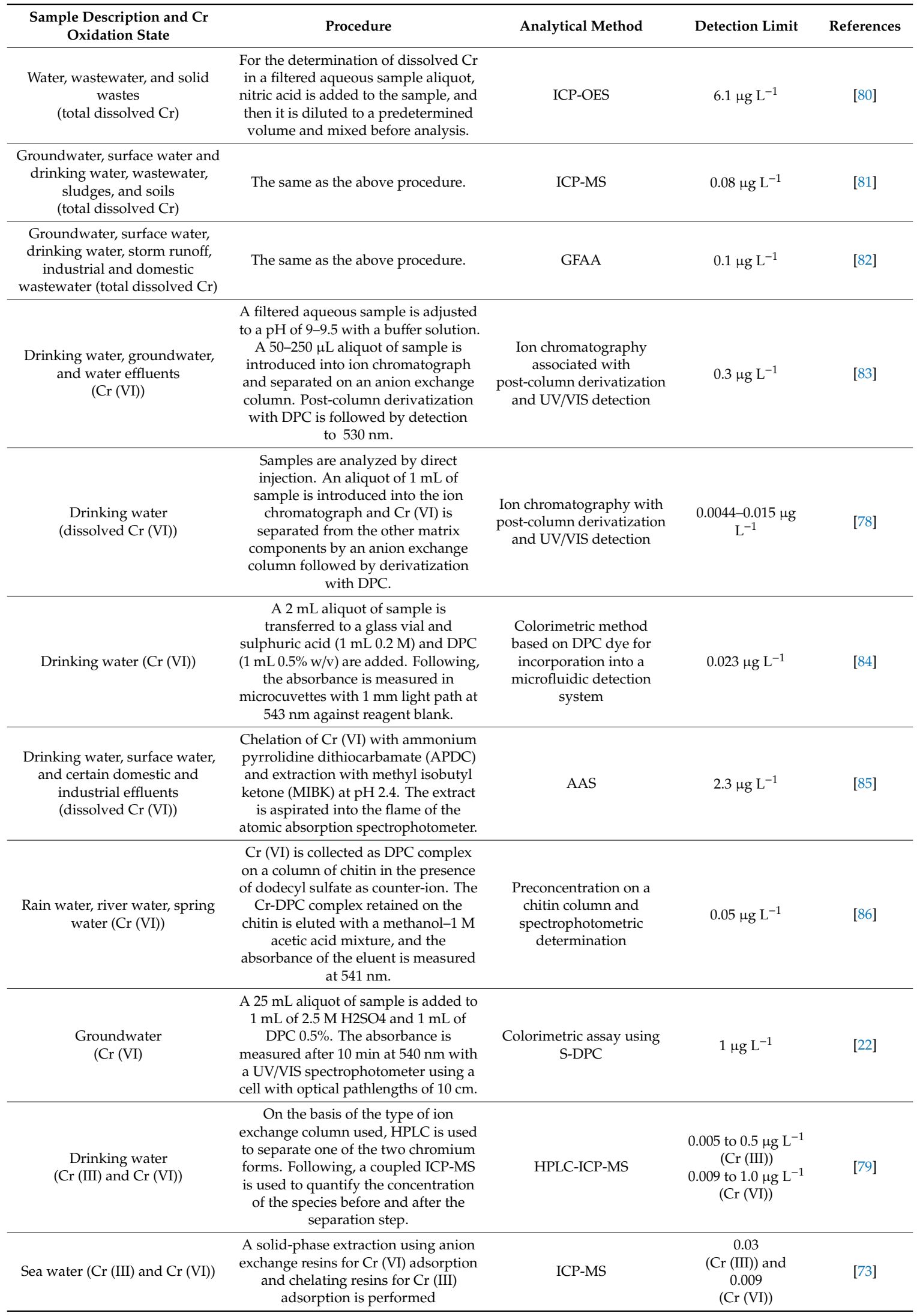




\section{Health Risk}

Biological effects of chromium strongly depend on its oxidation state [56,57]. $\mathrm{Cr}$ (III) is a nutritionally essential trace element, nontoxic and poorly absorbed [87]. Mussels, Broccoli, wholemeal flour, garlic, basil, potatoes are just some recommended food for chromium intakes [62]. Chromium (III) picolinate is a common dietary supplement. Trivalent chromium enhances insulin activity functioning as receptor binding, and decreases the risk for diabetes mellitus $[62,88]$. As a consequence, its deficiency results in disorders in glucose metabolism and glucose intolerance [16]. Assuming a fractional absorption value of $25 \%$, the daily requirement of absorbable $\mathrm{Cr}$ (III) is estimated to be $0.5-2 \mu \mathrm{g}$, provided by an intake of 2-8 $\mu$ g per day of $\mathrm{Cr}$ (III) [89]. However, an excess quantity of trivalent chromium above the recommended value may result in a long-term toxicity and carcinogenicity [87].

$\mathrm{Cr}(\mathrm{VI})$ is the most toxic form [16], producing liver and kidney damage, internal haemorrhage and respiratory disorders. It has been characterized as carcinogenic to humans (Group I) by the International Agency for Research on Cancer [90]. Cr (VI) can enter the body when people breathe air, eat food, or drink water containing it. Fortunately, human body has compartments and mechanisms for attenuating $\mathrm{Cr}(\mathrm{VI})$ toxicity, related to specific reducing activities of body fluids [91]. These mechanisms involve the saliva, gastric juice, intestinal bacteria, blood, liver, epithelial lining fluid, pulmonary alveolar macrophages, peripheral lung parenchyma, and bronchial tree [16,91-94].

All the deleterious health effects of chromium observed in humans are dose, exposure level and duration dependant [62]. In 1984, Korallus et al. [95] demonstrated that human plasma could reduce spontaneously $\mathrm{Cr}$ (VI) ions of up to $2 \mathrm{mg} \mathrm{L}^{-1}$ to $\mathrm{Cr}$ (III) and this capability could be enhanced by assuming ascorbic acid. But the intake of $\mathrm{Cr}(\mathrm{VI})$ in excess of plasma reduction capability as well as of the red blood cells reducing capacity (at least 93-128 mg) determines hematological changes [94]. Likewise higher doses of $\mathrm{Cr}(\mathrm{VI})$ depress the phagocytic activity of alveolar macrophages and the humoral immune response, whereas lower doses of $\mathrm{Cr}$ (VI) stimulate phagocytic activity of the alveolar macrophages and increase the humoral immune response [96].

In addition, there is a great deal of the relative health effects of the various routes of exposure for $\mathrm{Cr}$ (VI) [16]. Occupational exposure to $\mathrm{Cr}$ (VI) by inhalation depends upon the job function and industry, but can reach several hundred micrograms per cubic meter and it is associated with lung cancer $[1,62,90,97]$. Chronic inhalation exposure to hexavalent chromium results in effects on the respiratory tract, damaging the nasal septum with perforations and ulcerations, causing bronchitis, decreasing in lung function, pneumonia, and nasal itching and soreness [98]. With regards to dermal absorption through skin exposure to hexavalent chromium, it may cause contact dermatitis, sensitivity, and ulceration of the skin $[16,99]$. Ingestion is the most significant source of exposure for polluted drinking water [100]. Even if $\mathrm{Cr}$ (VI) ingested can be reduced to its trivalent form by saliva and gastric juice, the most part remains as absorbable chromium. Thus, ingested $\mathrm{Cr}(\mathrm{VI})$ through contaminated food and water may produce effects on the liver, kidney, gastrointestinal, immune systems, and blood [94,96]. Ingesting less than $2 \mathrm{~g}$ of $\mathrm{Cr}$ (VI) compound can result in kidney and liver damage after 1-4 days of exposure, while a dose of $2-5 \mathrm{~g}$ of a soluble hexavalent chromium compound can be fatal to an adult human [1].

The dose received through ingestion of polluted groundwater of the Aosta Valley region, Italy, was calculated by Tiwari \& De Maio [100] using Equation (1):

$$
\mathrm{ADD}=\left(\mathrm{C}_{\mathrm{W}} \times \mathrm{IR} \times \mathrm{EF} \times \mathrm{ED}\right) /(\mathrm{BW} \times \mathrm{AT})
$$

where ADD represents the average daily dose, unit in $\mathrm{mg} / \mathrm{kg} / \mathrm{day} ; \mathrm{Cw}$ is the concentration of chromium in water, unit in $\mu \mathrm{g} \mathrm{L}^{-1}$; IR is the ingestion rate, unit in $\mathrm{L} \mathrm{day}^{-1}$; $\mathrm{EF}$ is the exposure frequency, unit in days year ${ }^{-1}$; ED is the exposure duration, unit in years; BW is the body weight, unit in kg; and AT is the averaging time (days) [100]. 
Cellular Intake, Metabolism, and Toxicity of $\mathrm{Cr}$ (VI)

Cellular membranes are relatively impermeable to cationic trivalent chromium, as confirmed by in vitro and in vivo studies adding radioactive $\mathrm{Cr}$ (III) to whole blood [94].

On the contrary, $\mathrm{Cr}$ (VI) enters the cells by diffusion through a nonspecific anion channel [96]. Structural similarity of chromate ion to sulphate allows its easy entry through the general sulphate channels [42]. After crossing the cell membrane, chromium undergoes a series of metabolic reductions forming the unstable reaction intermediates, $\mathrm{Cr}(\mathrm{V})$ and $\mathrm{Cr}(\mathrm{IV})$, and finally the more stable form $\mathrm{Cr}$ (III) [94,101]. At physiological pH, intracellular reduction of $\mathrm{Cr}$ (VI) occurs involving several non-enzymatic and enzymatic antioxidants. Examples of non-enzymatic reducing agents are ascorbate (Asc), reduced glutathione (GSH) and cysteine (Cys) [102]. Asc reduces $\mathrm{Cr}$ (VI) via a two-electron reaction forming the reduction intermediate, $\mathrm{Cr}$ (IV). Reduction of $\mathrm{Cr}$ (VI) by GSH can be either by one- or two-electron reactions which produces $\mathrm{Cr}$ (V) or Cr (IV). Reduction by Cys is almost exclusively a one-electron reaction. A combined activity of Asc, GSH and Cys in cells reduces more than $95 \%$ of $\mathrm{Cr}$ (VI) into $\mathrm{Cr}$ (III) [101]. Other minor players in chromium intracellular reduction are cytochrome P450 reductase (only in absence of oxygen) and the mitochondrial electron transport complexes $[9,62,101]$. Thus, $\mathrm{Cr}(\mathrm{VI})$ is not directly responsible of genotoxicity. It does not react with macromolecules such as DNA, RNA, proteins and lipids [103]. The toxicity of hexavalent chromium within the cell is related to reduction process by generation of free radicals. $\mathrm{Cr}(\mathrm{VI}), \mathrm{Cr}(\mathrm{V}), \mathrm{Cr}(\mathrm{IV})$ and $\mathrm{Cr}$ (III) produce ROS through a Haber-Weiss reaction as shown in Figure $3[4,9,104]$. The intracellular oxidative stress produced by the above mentioned processes is directly or indirectly responsible of damages to macromolecules $[42,96]$. Cr (VI) metabolism products have been associated with the production of DNA-single strand or DNA-double strand breaks $[45,105,106]$. These can alter the function of cells leading to cancers. Also, the electrostatic interaction between stable $\mathrm{Cr}$ (III) species and negatively charged phosphate groups of DNA forms mutagenic and toxic $\mathrm{Cr}$ (III)-DNA complexes which affect the DNA replication and transcription [56]. The main pathways involved in chromium genotoxicity are summarized in Figure 4.

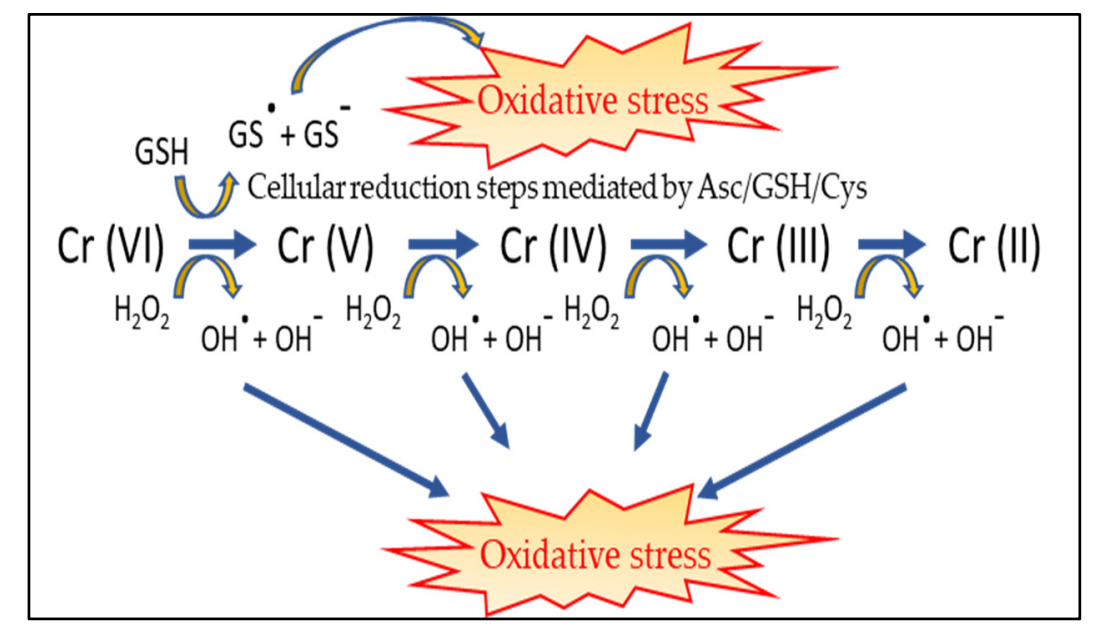

Figure 3. Schematic representation of free radicals formation during $\mathrm{Cr}$ (VI) reduction within the cell through Haber-Weiss reactions (modified from [15]). Asc, ascorbate; GSH, reduced glutathione; Cys, cysteine. 


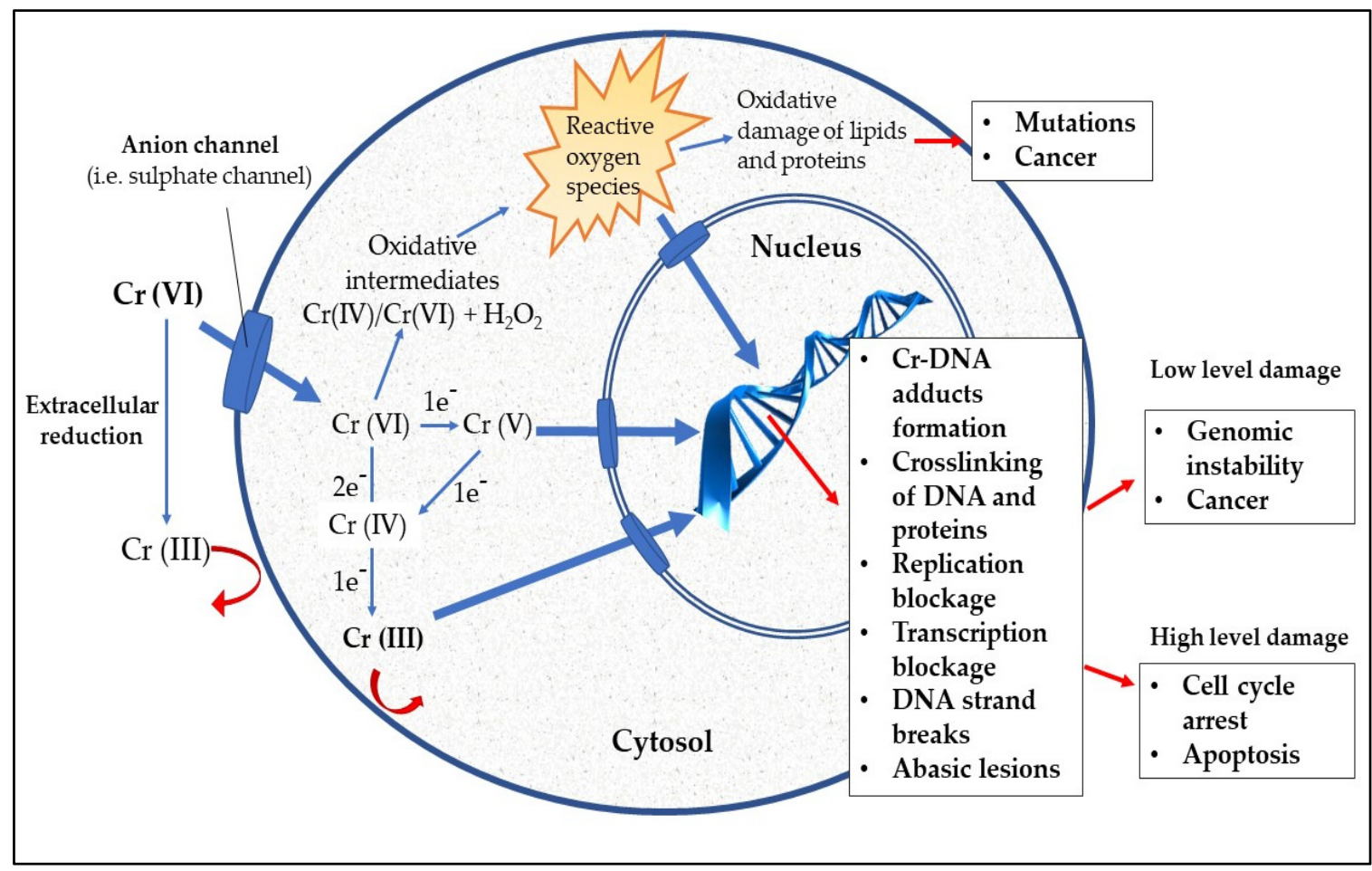

Figure 4. Cellular uptake and main pathways involved in chromium genotoxicity.

\section{Remediation Strategies}

The best-known disposal method of wastes and wastewaters enriched in chromium is often reduction of $\mathrm{Cr}$ (VI) to a less mobile and less toxic form, $\mathrm{Cr}$ (III), because $\mathrm{Cr}$ in industrial wastes occurs predominantly in the hexavalent form [27]. Some strategies used for chromium pollution remediation include chemical reduction methods by reducing agents such as Fe (0) and Fe (II), precipitation, adsorption, ion exchange, electrocoagulation, or biological reduction as a result of microbial metabolism [21,25,107-109].

\subsection{Physico-Chemical Tratments}

\subsubsection{Chemical Reduction}

Many reducing agents have been applied (typically in acidic media) for the treatment of $\mathrm{Cr}$ (VI) polluted wastewaters and groundwaters. Reductants include ferrous compounds and zerovalent iron [3]. The experiment by Katsoyannis et al. (2020) [47] suggested an autocatalytic effect of Cr (VI) concentration on its reduction by ferrous iron. Moreover, multiple additions of Fe (II) in water spiked with Cr (VI) seem to be more efficient than adding all required Fe (II) at once. A previous study by Stylianou et al. (2018) [110] found as optimum a molar ratio Fe (II)/Cr (VI) of around 3 for chromium reduction, thus reducing the overall quantity of reductive reagents and produced sludge. Moreover, the zero-valent iron (ZVI) and particularly the nanoscale zero-valent iron (nZVI) are well documented in the scientific literature as a readily available and low-cost reducing agent for Cr (VI) removal [111], although the ecotoxicological effects on native microorganisms are rarely considered [112]. Another limit of this treatment is related to the possible aggregation of the nZVI particles, which lower its efficiency. To overcome the issue, in recent years, nZVI was applied using porous media, that is, bentonite and sepiolite as solid support [112,113]. Other reducing agents used in acidic media are reduced sulphur compounds, hydrogen peroxide, and hydrazine. Sodium hydrosulphite (dithionite) can be used directly in alkaline conditions, but is not usually cost-effective [3]. 


\subsubsection{Adsorption and Ion Exchange}

Mechanical strength, osmotic stability and exchange capacity are characteristic of good adsorbents [114]. Parameters that influenced the adsorption rate are $\mathrm{pH}$, adsorbent dosage, contact time and initial concentration of contaminant $[115,116]$. Choppala et al. (2018) [117] found that Cr (VI) sorption can be enhanced by adding inorganic amendments, such as elemental sulphur. The positive effect of elemental sulphur on $\mathrm{Cr}(\mathrm{VI})$ sorption is mediated through a $\mathrm{pH}$ decrease. The increase of $\mathrm{Cr}(\mathrm{VI})$ adsorption in acidic to slightly alkaline conditions can be explained as surface complexation reaction between $\mathrm{Cr}(\mathrm{VI})$ species and surface hydroxyl sites which are the sites for ion exchange $[3,118]$.

Many researchers have focused on the application of natural and synthetic sorbents for chromium remediation including activated carbon, carbon nanotubes, modified clay and sand, and volcanic rocks such as pumice and scoria $[6,21,36,119,120]$. A class of well-known anionic clay minerals is layered double hydroxides (LDHs). These minerals consist of positively charged hydrotalcite-like host layers and charge-balanced interlayers of inorganic anions and water molecules that are apt to exchange with other anions owing to the weak interlayer bonding [115,121]. Moreover, biomaterials, such as raw materials derived from agriculture and forestry as well as biochar, can be applied as adsorbent materials due to their high porosity, surface area, and surface reactivity [12,122-124]. An important advantage of these kinds of sorbents is their inexpensiveness, which makes the process more sustainable. Another effective strategy for $\mathrm{Cr}(\mathrm{VI})$ removal includes the strong base anion exchange (SBA), which requires an inert polymeric resin activated with surface and interstitial exchangeable functional groups [125]. However, some considerations about efficient resin regeneration and waste minimization are important to improve operational, economic, and environmental performances of ion exchange [126].

\subsubsection{Electrocoagulation}

In the last decades, several studies [127-132] reported electrocoagulation processes for removing a high concentration of $\mathrm{Cr}(\mathrm{VI})$ from water and wastewater. Electrocoagulation is a process consisting of creating metallic hydroxide flocs inside the wastewater by electro dissolution of soluble anodes. Dermentzis et al. (2011) [133] found that some affecting parameters are $\mathrm{pH}$, applied current density, and time, while initial Cr (VI) did not influence its removal rate by electrocoagulation. By contrast, Zewail et al. (2014) [130] as well as Genawi et al. (2020) [132] found that the initial chromium concentration determines the efficiency of the treatment. The electrocoagulation is quicker than the chemical coagulation and produces less slime and less dissolved salts. The most used pairs of electrodes are made by $\mathrm{Fe}-\mathrm{Fe}, \mathrm{Al}-\mathrm{Al}$, or $\mathrm{Al}-\mathrm{Fe}$ [129]. In the case of iron anodes, the $\mathrm{Fe}$ (II) ions reduce $\mathrm{Cr}$ (VI) to $\mathrm{Cr}$ (III) in alkaline to neutral medium, while they are oxidized to $\mathrm{Fe}$ (III) ions, according to the following reaction: $\mathrm{CrO}_{4}{ }^{2-}+3 \mathrm{Fe}^{2+}+4 \mathrm{H}_{2} \mathrm{O}+4 \mathrm{OH}^{-} \rightarrow 3 \mathrm{Fe}(\mathrm{OH})_{3}+\mathrm{Cr}(\mathrm{OH})_{3}$ [133]. Consequently, both the Fe (III) and $\mathrm{Cr}$ (III) combine with $\mathrm{OH}$ - ions, forming insoluble hydroxides which precipitate.

\subsection{Bacterial Resistance and Remediation Capabilities}

The wide metabolic diversity of microorganisms makes their application possible in reclaiming a number of contamination scenarios [134]. In particular, bacteria represent a highly promising and cost-effective resource for chromium removal owing to their high plasticity and widespread presence. They are able to reduce the toxic of chromium $\mathrm{Cr}(\mathrm{VI})$ to the less toxic trivalent state, both as a survival mechanism aimed at reducing toxicity around the cell and as a means of deriving metabolic energy for cell growth [22,135]. Other strategies useful for $\mathrm{Cr}$ (VI) removal, which take advantage of bacterial resistance to high pollutant concentrations, include bioaccumulation and biosorption [136,137]. It should be noted that resistance and reduction are found to be independent properties of bacteria. Not all $\mathrm{Cr}(\mathrm{VI})$-resistant bacteria can reduce $\mathrm{Cr}(\mathrm{VI})$ to $\mathrm{Cr}$ (III). On the other hand, there are non-resistant bacteria that can reduce $\mathrm{Cr}(\mathrm{VI})$, although their growth is significantly inhibited at high chromate concentrations [23]. 


\subsubsection{Biosorption}

It has been demonstrated that bacteria can facilitate the removal of metal species from aquatic solutions owing to adsorptive properties of their cellular surface [138-140]. The biosorption of heavy metal ions by microorganisms is influenced by several parameters including specific surface properties of the microorganism (biosorbent), the amount of biomass, physico-chemical parameters of the solution such as temperature, $\mathrm{pH}$, initial metal ion concentration, and the existence of other ions [141]. Asri et al. (2017) [142] studied the biosorption potential of seven bacterial strains isolated from a polluted site, finding a high significant positive correlation between $\mathrm{Cr}(\mathrm{VI})$ removal by strains and their acceptor electron character $\gamma^{+}(\mathrm{r}=0.90)$. Moreover, a significant negative correlation between the $\mathrm{Cr}(\mathrm{VI})$ removal potential and their donor electron character $\gamma^{-}(\mathrm{r}=-0.746)$ was observed. The presence of anionic ligands on bacterial cell wall (carboxyl, amine, hydroxyl, phosphate, and sulfhydryl groups) has a relevant role in metal sequestration from water [143].

Biosorption of heavy metals can be metabolically mediated (with ATP consumption) by living cells or a spontaneous physico-chemical pathway of uptake, which can occur both by living and dead cells [141]. Although the adsorption rate can be higher using dead biomass, living microorganisms are preferred for bioremediation because living cells are capable of a continuous metal uptake and self-replenishment [141,144].

\subsubsection{Bioaccumulation}

$\mathrm{Cr}$ (VI)-resistant/tolerant bacterial strains can also accumulate heavy metals within the cells and sequestrate them from the surrounding environment. The concentration of metals inside the cells can result from the interaction with surface ligands (biosorption) followed by passive or active transport into the cell [145]. The combination of active and passive uptake is called "bioaccumulation" [146]. In contrast to other metals, which occur predominantly as cationic species, chromium exists mainly in the oxyanion form (i.e., $\mathrm{CrO}_{4}{ }^{2-}$ ), and thus cannot be trapped by the anionic components of bacterial envelopes [147]. Owing to its similarity to $\mathrm{SO}_{4}{ }^{2-}$ anion, $\mathrm{Cr}$ (VI) can be easily transported across biological membranes via active sulphate transporters. Srinath et al. (2002) [148] found two bacterial strains isolated from tannery waste Bacillus circulans and Bacillus megaterium, able to bioaccumulate 34.5 and $32.0 \mathrm{mg} \mathrm{Cr} \mathrm{g}^{-1}$ dry weight, respectively.

After its cellular intake, $\mathrm{Cr}(\mathrm{VI})$ undergoes reduction processes.

Raman et al. (2018) [149] studied the bioremediation potential of Stenotrophomonas maltophilia isolated from tannery effluent, revealing a $\mathrm{Cr}(\mathrm{VI})$ bioaccumulation rate higher than its reduction.

\subsubsection{Bioreduction}

Bacteria capable of reducing $\mathrm{Cr}$ (VI) mainly belong to nitrate-reducing, Fe (III)-reducing, and sulphate-reducing bacteria. Among the gram positive bacteria, Bacillus, Deinococcus, and Arthrobacter have shown Cr (VI) reduction capability [107,150,151]. Meanwhile, Enterococcus, Shewanella, Pseudomonas, Escherichia, Thermus, and Ochrobactrum are examples of gram-negative bacteria with potential application in bioremediation [152-157]. Microbial reduction is one of the most promising routes for in situ reclamation of $\mathrm{Cr}(\mathrm{VI})$ polluted groundwater $[22,158]$.

$\mathrm{Cr}$ (VI) reduction is observed to occur both enzymatically and chemically via the reducing agents $\mathrm{Fe}$ (II) and $\mathrm{H}_{2} \mathrm{~S}$ produced by bacteria [159]. Several compounds, such as cytochrome c on cell surface, intracellular nicotinamide adenine dinucleotide (NADH), extracellular polymeric substances such as extracellular protein, polysaccharide, and humic-like substances, may be involved in $\mathrm{Cr}$ (VI) reduction [160]. Particularly, cytochrome $\mathrm{c}$ is a heme protein localized in the inner and outer membranes, which is involved in the direct reduction of $\mathrm{Cr}$ (VI) to $\mathrm{Cr}$ (III) through electron transfer across the respiratory chain [161]. NADH is a coenzyme that functions as a hydride donor for chromate reductase to detoxify $\mathrm{Cr}(\mathrm{VI})$. 
According to Ackerley et al. (2004), chromate reductase can be divided into two groups named class I and class II, based on sequence homology.

Two of the most studied class I reductase are ChrR and YieF [162,163]. ChrR from Pseudomonas putida is one of the best studied $\mathrm{Cr}$ (VI) reductases and has an NADH-dependent activity. A study on chromate stress in Escherichia coli by Ackerley et al. (2006) [164] using enzyme mutants revealed that ChrR protects against chromate toxicity, preventing chromate reduction by the cellular one-electron reducers, thereby minimizing reactive oxygen species (ROS) generation [165]. YieF is a dimeric flavoprotein that reduces $\mathrm{Cr}$ (VI) to $\mathrm{Cr}$ (III) through a four-electron transfer, where three electrons are consumed in $\mathrm{Cr}$ (VI) reduction and the fourth electron is transferred to oxygen [23].

The nitroreductases NfsA, a common enzyme in the genera Bacillus, possesses $\mathrm{Cr}$ (VI) reductase activity as a secondary function and belongs to class II [166]. This enzyme mediates one-electron reduction processes forming the $\mathrm{Cr}(\mathrm{V})$ intermediate, leading to high reactive oxygen species generation [152]. This secondary function is possibly the result of bacterial enzymatic adaptation to the relatively recent increase of $\mathrm{Cr}(\mathrm{VI})$ content in the environment caused by anthropogenic activities [165].

\subsection{Comparison between Chemical and Biological Strategies for $\mathrm{Cr}$ (VI) Remediating}

All the above-mentioned techniques (see Sections 6.1 and 6.2) present advantages and disadvantages, as summarized in Table 4. Thus, the best choice for chromium remediation needs a site-specific and accurate evaluation [167]. This is true especially for in situ interventions, which require a thorough understanding of the geochemistry, hydrogeology, microbiology, and ecology of contaminated matrices [134]. Cost-benefit analyses are often used, occasionally in concert with comparative risk assessment, to choose between competing project alternatives [168]. The efficiency rate of each treatment can be affected by inherent properties of the polluted matrix and the achievement of the experimental conditions optimum. The efficiency of some physico-chemical and biological treatments reported in the recent literature is summarized in Table 5.

Table 4. Summary of the main advantages and disadvantages of common chemical and biological treatments for $\mathrm{Cr}$ (VI) removal. nZVI, nanoscale zero-valent iron.

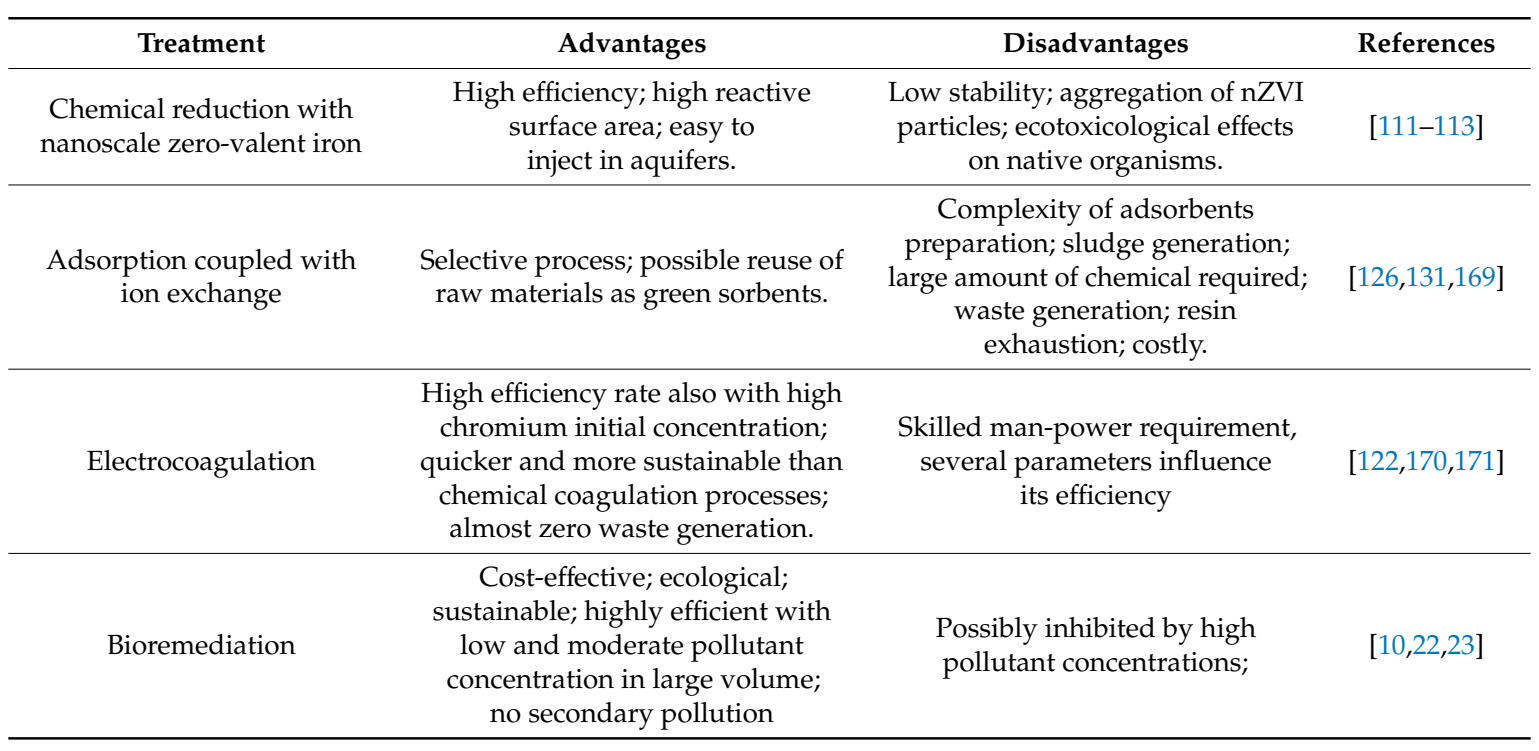

Table 5. Efficiency rate of some chemical and biological strategies reported in the recent literature.

\begin{tabular}{cccc}
\hline $\begin{array}{c}\text { Cr (VI) Initial } \\
\text { Concentration }\end{array}$ & Treatment & Removal Efficiency (\%) & References \\
\hline $50 \mu \mathrm{g} \mathrm{L}^{-1}$ & Reduction by $1 \mathrm{mg} \mathrm{L}^{-1}$ of ferrous iron, & $92 \%$ & {$[47]$} \\
$300 \mu \mathrm{g} \mathrm{L}^{-1}$ & $\mathrm{Fe}(\mathrm{II}) / \mathrm{Cr}$ (VI) in a molar ratio of around 3 & Above $90 \%$ & {$[110]$} \\
$0.6 \mathrm{mg} \mathrm{L}^{-1}$ & Reduction by bentonite-supported nZVI & Above $90 \%$ & {$[112]$} \\
\hline
\end{tabular}


Table 5. Cont.

\begin{tabular}{|c|c|c|c|}
\hline $\begin{array}{l}\mathrm{Cr} \text { (VI) Initial } \\
\text { Concentration }\end{array}$ & Treatment & Removal Efficiency (\%) & References \\
\hline $50 \mathrm{mg} \mathrm{L}^{-1}$ & Electrocoagulation with $\mathrm{Al}-\mathrm{Al}$ as pair of electrodes & $42 \%$ & [128] \\
\hline $55.3 \mathrm{mg} \mathrm{L}^{-1}$ & Electrocoagulation with Fe-Fe as pair of electrodes & $91.7 \%$ & [131] \\
\hline $5 \mathrm{mg} \mathrm{L}^{-1}$ & Electrocoagulation with $\mathrm{Al}$ alloy-Fe as pair of electrodes & $98.2 \%$ & [130] \\
\hline $1 \mathrm{mg} \mathrm{L}^{-1}$ & Adsorption onto modified carbon nanotubes & $87 \%$ & [172] \\
\hline $30 \mathrm{mg} \mathrm{L}^{-1}$ & Adsorption using biochar from Camellia oleifera seed shell & $99.99 \%$ & {$[124]$} \\
\hline $0.5 \mathrm{mg} \mathrm{L}^{-1}$ & Adsorption onto pumice (VPum) and scoria (VSco) & $\begin{array}{l}80 \% \text { and } 77 \% \text {, } \\
\text { respectively }\end{array}$ & [6] \\
\hline $50 \mathrm{mg} \mathrm{L}^{-1}$ & Sulphur-based mixotrophic bio-reduction & $95.5 \%$ & [160] \\
\hline $1000 \mu \mathrm{g} \mathrm{L}^{-1}$ & $\begin{array}{l}\text { Bioreduction by indigenous microorganisms enhanced by } \\
\text { yeast extract addition }\end{array}$ & $99.47 \%$ & [22] \\
\hline $50 \mathrm{mg} \mathrm{L}^{-1}$ & $\begin{array}{l}\text { Bioreduction by mixed bacterial consortium enhanced by } \\
\text { phosphorus minerals addition }\end{array}$ & about $50 \%$ & [166] \\
\hline $100 \mathrm{mg} \cdot \mathrm{L}^{-1}$ & $\begin{array}{l}\text { Biosorption using bacterial lawn deposited on membrane } \\
\text { (seven bacterial strains tested) }\end{array}$ & from 5.32 to $99.87 \%$ & [142] \\
\hline
\end{tabular}

\section{Conclusions}

Chromium pollution of waters and groundwaters represents a serious environmental problem for EU countries. Thermal power stations and other combustion installations, followed by waste and wastewater management plants, are the most relevant industrial contributors to chromium emission in water. Among the possible forms of chromium, the hexavalent one is the most toxic because it can cause dangerous damage to human health. The genotoxicity of chromium, once it is introduced into human cells, can manifest favouring genomic instability, cancer onset, cell cycle arrest, and apoptosis. Consequently, the choice of the optimal remediation strategies for recovering waters and groundwaters from $\mathrm{Cr}$ pollution is a crucial step for both technicians and public administrators. In the last decade, several technologies have been tested in order to verify their efficiency in achieving chromium decontamination. Physico-chemical methods reveal high capabilities in removing this pollutant, but at the same time, show high costs of application. Differently, bioremediation approaches are more sustainable both in terms of costs than concerning the impacts on the treated matrices (waters/groundwaters), leading to no secondary pollution. Nevertheless, living organisms used for reclamation interventions can be inhibited by a higher concentration of the pollutant. Thus, there is no strategy that is the absolute best. A thorough understanding of the geochemistry, hydrogeology, microbiology, and ecology of the polluted matrix, together with a cost-benefit analysis, are required to choose between competing project alternatives. The comparison between physico-chemical and biological methods for $\mathrm{Cr}(\mathrm{VI})$ decontamination proposed in this work can be useful to evaluate and customize the opportune chromium remediation strategy.

Author Contributions: Conceptualization, M.T. and V.A.; Writing-original draft preparation, M.T., V.A., D.D.P., D.L., C.C., and C.M.; Writing-review and editing, V.A. and M.T.; Providing case and idea: V.A., M.T., and V.F.U.; supervision: V.A.; References collection: M.T., D.D.P., D.L., C.C., and C.M.; funding acquisition: V.F.U. All authors have read and agreed to the published version of the manuscript.

Funding: This work was supported by the project "Analisi di fattibilità degli interventi di messa in sicurezza e bonifica, noti i profili degli inquinanti rilevati e delle relative misure di contenimento-Convenzione tra Comune di Barletta e CNR-IRSA di Bari del 08/02/2018".

Conflicts of Interest: The authors declare no conflict of interest. 


\section{Appendix A}

Table A1. Amount of chromium and its compounds released in European waters per industrial activity, data from the European Environment Agency related to the year 2017 (data source: [44]).

\begin{tabular}{|c|c|c|c|c|}
\hline Rank & Industrial Activities & Facilities & Tons & $\%$ \\
\hline 1 & Energy sector & 74 & 699.94 & 83.9 \\
\hline 1.a & Thermal power stations and other combustion installations & 59 & 699.30 & 83.8 \\
\hline $1 . b$ & Mineral oil and gas refineries & 15 & 0.64 & 0.1 \\
\hline 2 & Waste and wastewater management & 248 & 90.99 & 10.9 \\
\hline 2.a & Urban wastewater treatment plants & 215 & 84.30 & 10.1 \\
\hline $2 . b$ & $\begin{array}{c}\text { Independently operated industrial wastewater treatment plants } \\
\text { serving a listed activity }\end{array}$ & 11 & 2.63 & 0.3 \\
\hline 2.c & Disposal or recovery of hazardous waste & 6 & 2.15 & 0.3 \\
\hline 2.d & Disposal of non-hazardous waste & 11 & 1.39 & 0.2 \\
\hline 2.e & Landfills (excluding landfills closed before the 16/7/2001) & 3 & 0.52 & 0.1 \\
\hline 2.f & $\begin{array}{l}\text { Incineration of non-hazardous waste included in Directive } \\
\text { 2000/76/EC - waste incineration }\end{array}$ & 2 & - & 0.0 \\
\hline 3 & Production and processing of metals & 93 & 18.50 & 2.2 \\
\hline 3.a & $\begin{array}{l}\text { Surface treatment of metals and plastics using electrolytic } \\
\text { or chemical processes }\end{array}$ & 17 & 9.04 & 1.1 \\
\hline 3.b & Production of pig iron or steel including continuous casting & 45 & 5.84 & 0.7 \\
\hline 3.c & $\begin{array}{c}\text { Production of non-ferrous crude metals from ore, concentrates, } \\
\text { or secondary raw materials }\end{array}$ & 13 & 1.79 & 0.2 \\
\hline 3.d & Metal ore (including sulphide ore) roasting or sintering installations & 6 & 1.32 & 0.2 \\
\hline 3.e & Processing of ferrous metals & 7 & 0.51 & 0.1 \\
\hline $3 . f$ & Ferrous metal foundries & 5 & - & 0.0 \\
\hline 4 & Chemical industry & 39 & 17.89 & 2.1 \\
\hline 4.a & Industrial scale production of basic inorganic chemicals & 14 & 8.65 & 1.0 \\
\hline 4.b & Industrial scale production of basic organic chemicals & 19 & 8.15 & 1.0 \\
\hline 4.c & Industrial scale production of basic plant health products and of biocides & 2 & 0.77 & 0.1 \\
\hline 4.d & $\begin{array}{c}\text { Industrial scale production of phosphorous, nitrogen, } \\
\text { or potassium-based fertilizers }\end{array}$ & 2 & 0.15 & 0.0 \\
\hline 4.e & Industrial scale production of basic pharmaceutical products & 1 & 0.09 & 0.0 \\
\hline 5 & Mineral industry & 24 & 3.99 & 0.5 \\
\hline 5.a & Underground mining and related operations & 11 & 3.23 & 0.4 \\
\hline $5 . \mathrm{b}$ & Opencast mining and quarrying & 5 & 0.76 & 0.1 \\
\hline 5.c & Production of cement clinker or lime in rotary kilns or other furnaces & 3 & - & - \\
\hline 5.d & $\begin{array}{c}\text { Manufacture of ceramic products including tiles, bricks, } \\
\text { stoneware, or porcelain }\end{array}$ & 1 & - & - \\
\hline 5.e & Manufacture of glass, including glass fibre & 4 & - & - \\
\hline 6 & Paper and wood production processing & 29 & 2.43 & 0.3 \\
\hline 6.a & Production of pulp from timber or similar fibrous materials & 20 & 2.03 & 0.2 \\
\hline $6 . b$ & Production of paper and board and other primary wood products & 9 & 0.40 & 0.0 \\
\hline 7 & Animal and vegetable products from the food and beverage sector & 1 & 0.16 & 0.0 \\
\hline 7.a & Treatment and processing of milk & 1 & 0.16 & 0.0 \\
\hline 8 & Other activities & 4 & 0.37 & 0.0 \\
\hline 8.a & Pre-treatment or dyeing of fibres or textiles & 2 & 0.18 & 0.0 \\
\hline 8.b & Tanning of hides and skins & 1 & 0.11 & 0.0 \\
\hline \multirow[t]{2}{*}{ 8.c } & Surface treatment of substances, objects, or products using organic solvents & 1 & 0.08 & 0.0 \\
\hline & Total & 512 & 834.26 & \\
\hline
\end{tabular}

\section{References}

1. Sharma, S.K.; Petrusevski, B.; Amy, G. Chromium removal from water: A review. J. Water Supply Res. Technol.-Aqua 2008, 57, 541-553. [CrossRef]

2. Unceta, N.; Séby, F.; Malherbe, J.; Donard, O.F.X. Chromium speciation in solid matrices and regulation: A review. Anal. Bioanal. Chem. 2010, 397, 1097-1111. [CrossRef] [PubMed]

3. Rai, D.; Eary, L.E.; Zachara, J.M. Environmental chemistry of chromium. Sci. Total Environ. 1989, 86, $15-23$. [CrossRef] 
4. Bokare, A.D.; Choi, W. Advanced Oxidation Process Based on the $\mathrm{Cr}(\mathrm{III}) / \mathrm{Cr}(\mathrm{VI})$ Redox Cycle. Environ. Sci. Technol. 2011, 45, 9332-9338. [CrossRef]

5. Bianco Prevot, A.; Ginepro, M.; Peracaciolo, E.; Zelano, V.; De Luca, D.A. Chemical vs bio-mediated reduction of hexavalent chromium. An in-vitro study for soil and deep waters remediation. Geoderma 2018, 312, 17-23. [CrossRef]

6. Alemayehu, E.; Thiele-Bruhn, S.; Lennartz, B. Adsorption behaviour of $\mathrm{Cr}(\mathrm{VI})$ onto macro and micro-vesicular volcanic rocks from water. Sep. Purif. Technol. 2011, 78, 55-61. [CrossRef]

7. Zhang, R.; Xiang, Y.; Ran, Q.; Deng, X.; Xiao, Y.; Xiang, L.; Li, Z. Involvement of Calcium, Reactive Oxygen Species, and ATP in Hexavalent Chromium-Induced Damage in Red Blood Cells. Cell Physiol. Biochem. 2014, 34, 1780-1791. [CrossRef]

8. Wilbur, S.; Abadin, H.; Fay, M.; Yu, D.; Tencza, B.; Ingerman, L.; Klotzbach, J.; James, S. Health Effects; Agency for Toxic Substances and Disease Registry (US): Atlanta, GA, USA, 2012.

9. Wise, J.T.F.; Wang, L.; Xu, J.; Zhang, Z.; Shi, X. Oxidative stress of Cr(III) and carcinogenesis. In The Nutritional Biochemistry of Chromium (III); Elsevier: Amsterdam, The Netherlands, 2019; pp. 323-340. ISBN 978-0-444-64121-2.

10. Mishra, S.; Bharagava, R.N. Toxic and genotoxic effects of hexavalent chromium in environment and its bioremediation strategies. J. Environ. Sci. Health Part C 2016, 34, 1-32. [CrossRef]

11. Brasili, E.; Bavasso, I.; Petruccelli, V.; Vilardi, G.; Valletta, A.; Bosco, C.D.; Gentili, A.; Pasqua, G.; Di Palma, L. Remediation of hexavalent chromium contaminated water through zero-valent iron nanoparticles and effects on tomato plant growth performance. Sci. Rep. 2020, 10, 1920. [CrossRef]

12. Ashraf, A.; Bibi, I.; Niazi, N.K.; Ok, Y.S.; Murtaza, G.; Shahid, M.; Kunhikrishnan, A.; Li, D.; Mahmood, T. Chromium(VI) sorption efficiency of acid-activated banana peel over organo-montmorillonite in aqueous solutions. Int. J. Phytoremed. 2017, 19, 605-613. [CrossRef]

13. Kazakis, N.; Kantiranis, N.; Kalaitzidou, K.; Kaprara, E.; Mitrakas, M.; Frei, R.; Vargemezis, G.; Tsourlos, P.; Zouboulis, A.; Filippidis, A. Origin of hexavalent chromium in groundwater: The example of Sarigkiol Basin, Northern Greece. Sci. Total Environ. 2017, 593-594, 552-566. [CrossRef] [PubMed]

14. Jones, A.S.; Marini, J.; Solo-Gabriele, H.M.; Robey, N.M.; Townsend, T.G. Arsenic, copper, and chromium from treated wood products in the U.S. disposal sector. Waste Manag. 2019, 87, 731-740. [CrossRef] [PubMed]

15. Achmad, R.T.; Budiawan;Auerkari, E.I. Effects of Chromium on Human Body. ARRB 2017, 13, 1-8. [CrossRef]

16. Pellerin, C.; Booker, S.M. Reflections on hexavalent chromium: Health hazards of an industrial heavyweight. Environ. Health Perspect. 2000, 108, A402-A407. [CrossRef] [PubMed]

17. Yang, Y.; Ma, H.; Chen, X.; Zhu, C.; Li, X. Effect of incineration temperature on chromium speciation in real chromium-rich tannery sludge under air atmosphere. Environ. Res. 2020, 183, 109159. [CrossRef] [PubMed]

18. Vaiopoulou, E.; Gikas, P. Regulations for chromium emissions to the aquatic environment in Europe and elsewhere. Chemosphere 2020, 254, 126876. [CrossRef]

19. Munn, S.J.; Allanou, R.; Aschberger, K.; Berthault, F.; Cosgrove, O.; Luotamo, M.; Pakalin, S.; Paya-Perez, A.; Pellegrini, G.; Schwarz-Schulz, B.; et al. Chromium Trioxide, Sodium Chromate, Sodium Dichromate, Ammonium Dichromate, Potassium Dichromate, EUR 21508 EN; European Union Risk Assessment Report; Office for Official Publications of the European Communities: Luxembourg, 2005; Volume 53.

20. Feng, Z.-Q.; Yuan, X.; Wang, T. Porous polyacrylonitrile/graphene oxide nanofibers designed for high efficient adsorption of chromium ions (VI) in aqueous solution. Chem. Eng. J. 2020, 392, 123730. [CrossRef]

21. Dhal, B.; Thatoi, H.N.; Das, N.N.; Pandey, B.D. Chemical and microbial remediation of hexavalent chromium from contaminated soil and mining/metallurgical solid waste: A review. J. Hazard. Mater. 2013, 250-251, 272-291. [CrossRef]

22. Ancona, V.; Campanale, C.; Tumolo, M.; De Paola, D.; Ardito, C.; Volpe, A.; Uricchio, V.F. Enhancement of Chromium (VI) Reduction in Microcosms Amended with Lactate or Yeast Extract: A Laboratory-Scale Study. Int. J. Environ. Res. Public Health 2020, 17, 704. [CrossRef]

23. Thatoi, H.; Das, S.; Mishra, J.; Rath, B.P.; Das, N. Bacterial chromate reductase, a potential enzyme for bioremediation of hexavalent chromium: A review. J. Environ. Manag. 2014, 146, 383-399. [CrossRef]

24. Garbisu, C.; Garaiyurrebaso, O.; Epelde, L.; Grohmann, E.; Alkorta, I. Plasmid-Mediated Bioaugmentation for the Bioremediation of Contaminated Soils. Front. Microbiol. 2017, 8, 1966. [CrossRef] [PubMed]

25. Ma, L.; Xu, J.; Chen, N.; Li, M.; Feng, C. Microbial reduction fate of chromium (Cr) in aqueous solution by mixed bacterial consortium. Ecotoxicol. Environ. Saf. 2019, 170, 763-770. [CrossRef] [PubMed] 
26. Al-Battashi, H.; Joshi, S.J.; Pracejus, B.; Al-Ansari, A. The Geomicrobiology of Chromium (VI) Pollution: Microbial Diversity and its Bioremediation Potential. TOBIOTJ 2016, 10, 379-389. [CrossRef]

27. Koleli, N.; Demir, A. Chromite. In Environmental Materials and Waste; Academic Press: London, UK, 2016; pp. 245-263. ISBN 978-0-12-803837-6.

28. Sanchez-Segado, S.; Makanyire, T.; Escudero-Castejon, L.; Hara, Y.; Jha, A. Reclamation of reactive metal oxides from complex minerals using alkali roasting and leaching-An improved approach to process engineering. Green Chem. 2015, 17, 2059-2080. [CrossRef]

29. Haldar, S.K. Introduction. In Platinum-Nickel-Chromium Deposits; Elsevier: Amsterdam, The Netherlands, 2017; pp. 1-35. ISBN 978-0-12-802041-8.

30. Escudero-Castejon, L.; Sanchez-Segado, S.; Parirenyatwa, S.; Jha, A. Formation of Chromium-Containing Molten Salt Phase during Roasting of Chromite Ore with Sodium and Potassium Hydroxides. J. Manuf. Sci. Prod. 2016, 16, 215-225. [CrossRef]

31. Ripley, E.M.; Li, C. Chapter 3-Metallic Ore Deposits Associated With Mafic to Ultramafic Igneous Rocks. In Processes and Ore Deposits of Ultramafic-Mafic Magmas through Space and Time; Mondal, S.K., Griffin, W.L., Eds.; Elsevier: Amsterdam, The Netherlands, 2018; pp. 79-111. ISBN 978-0-12-811159-8.

32. Chrysochoou, M.; Theologou, E.; Bompoti, N.; Dermatas, D.; Panagiotakis, I. Occurrence, Origin and Transformation Processes of Geogenic Chromium in Soils and Sediments. Curr. Pollut. Rep. 2016, 2, 224-235. [CrossRef]

33. Ferronato, N.; Torretta, V. Waste Mismanagement in Developing Countries: A Review of Global Issues. Int. J. Environ. Res. Public Health 2019, 16, 1060. [CrossRef] [PubMed]

34. Gorny, J.; Billon, G.; Noiriel, C.; Dumoulin, D.; Lesven, L.; Madé, B. Chromium behavior in aquatic environments: A review. Environ. Rev. 2016, 24, 503-516. [CrossRef]

35. Zhou, B.; Huang, D.; Wu, J.; Zhu, Q.; Zhu, H. Horizontal and Vertical Distributions of Chromium in a Chromate Production District of South Central China. Int. J. Environ. Res. Public Health 2018, 15, 571. [CrossRef]

36. Mcleod, N. Chemical Immobilisation of Chromium Wastes using Modified Smectite Clays (E-clays). Environ. Geochem. Health 2001, 23, 273-279. [CrossRef]

37. Gattullo, C.E.; Allegretta, I.; Porfido, C.; Rascio, I.; Spagnuolo, M.; Terzano, R. Assessing chromium pollution and natural stabilization processes in agricultural soils by bulk and micro X-ray analyses. Environ. Sci. Pollut. Res. 2020. [CrossRef]

38. Vogel, C.; Hoffmann, M.C.; Krüger, O.; Murzin, V.; Caliebe, W.; Adam, C. Chromium (VI) in phosphorus fertilizers determined with the diffusive gradients in thin-films (DGT) technique. Environ. Sci. Pollut. Res. 2020. [CrossRef] [PubMed]

39. Coyte, R.M.; McKinley, K.L.; Jiang, S.; Karr, J.; Dwyer, G.S.; Keyworth, A.J.; Davis, C.C.; Kondash, A.J.; Vengosh, A. Occurrence and distribution of hexavalent chromium in groundwater from North Carolina, USA. Sci. Total Environ. 2020, 711, 135135. [CrossRef] [PubMed]

40. Dokou, Z.; Karagiorgi, V.; Karatzas, G.P.; Nikolaidis, N.P.; Kalogerakis, N. Large scale groundwater flow and hexavalent chromium transport modeling under current and future climatic conditions: The case of Asopos River Basin. Environ. Sci. Pollut. Res. 2016, 23, 5307-5321. [CrossRef] [PubMed]

41. Rajapaksha, A.U.; Vithanage, M.; Ok, Y.S.; Oze, C. Cr(VI) Formation Related to Cr(III)-Muscovite and Birnessite Interactions in Ultramafic Environments. Available online: https:/pubs.acs.org/doi/pdf/10.1021/es4015025 (accessed on 3 June 2020).

42. Zhitkovich, A. Chromium in Drinking Water: Sources, Metabolism, and Cancer Risks. Chem. Res. Toxicol. 2011, 24, 1617-1629. [CrossRef]

43. Benítez, S.V.B. Understanding of (Bio)geochemical Processes which Control Chromium Release, Speciation and Isotopic Fractionation in Ultramafic Environments Impacted by Mining Activitites. Ph.D. Thesis, Università Degli Studi, Cassino, Italy, 2018.

44. European Environment Agency. European Pollutant Release and Transfer Register. Available online: https://prtr.eea.europa.eu/\#/pollutantreleases (accessed on 19 May 2020).

45. Vimercati, L.; Gatti, M.F.; Gagliardi, T.; Cuccaro, F.; De Maria, L.; Caputi, A.; Quarato, M.; Baldassarre, A. Environmental exposure to arsenic and chromium in an industrial area. Environ. Sci. Pollut. Res. 2017, 24, 11528-11535. [CrossRef] 
46. Liu, H.; Wang, Y.; Zhang, H.; Huang, G.; Yang, Q.; Wang, Y. Synchronous detoxification and reduction treatment of tannery sludge using Cr (VI) resistant bacterial strains. Sci. Total Environ. 2019, 687, $34-40$. [CrossRef]

47. Katsoyiannis, I.A.; Xanthopoulou, M.; Zouboulis, A.I. Cr(VI) Femoval from Ground Waters by Ferrous Iron Redox-Assisted Coagulation in a Continuous Treatment Unit Comprising a Plug Flow Pipe Reactor and Downflow Sand Filtration. Appl. Sci. 2020, 10, 802. [CrossRef]

48. Oruko Ongon'g, R.; Edokpayi, J.N.; Msagati, T.A.M.; Tavengwa, N.T.; Ijoma, G.N.; Odiyo, J.O. The Potential Health Risk Associated with Edible Vegetables Grown on Cr(VI) Polluted Soils. Int. J. Environ. Res. Public Health 2020, 17, 470. [CrossRef]

49. Gong, Y.; Werth, C.J.; He, Y.; Su, Y.; Zhang, Y.; Zhou, X. Intracellular versus extracellular accumulation of Hexavalent chromium reduction products by Geobacter sulfurreducens PCA. Environ. Pollut. 2018, 240, 485-492. [CrossRef]

50. Tsiridis, V.; Petala, M.; Samaras, P.; Kungolos, A.; Sakellaropoulos, G.P. Environmental hazard assessment of coal fly ashes using leaching and ecotoxicity tests. Ecotoxicol. Environ. Saf. 2012, 84, 212-220. [CrossRef] [PubMed]

51. Darakas, E.; Tsiridis, V.; Petala, M.; Kungolos, A. Hexavalent chromium release from lignite fly ash and related ecotoxic effects. J. Environ. Sci. Health A Toxic Hazard. Subst. Environ. Eng. 2013, 48, 1390-1398. [CrossRef] [PubMed]

52. Ribé, V.; Nehrenheim, E.; Odlare, M. Assessment of mobility and bioavailability of contaminants in MSW incineration ash with aquatic and terrestrial bioassays. Waste Manag. 2014, 34, 1871-1876. [CrossRef] [PubMed]

53. Joseph, A.; Snellings, R.; Van den Heede, P.; Matthys, S.; De Belie, N. The Use of Municipal Solid Waste Incineration Ash in Various Building Materials: A Belgian Point of View. Materials 2018, 11, 141. [CrossRef]

54. European Commission. Establishing a Framework for Community Action in the Field of Water Policy (L327/1-72). European Council Directive, 2000/60/EC (Water Framework Directive); European Commission: Brussels, Belgium, 2000.

55. Kimbrough, D.E.; Cohen, Y.; Winer, A.M.; Creelman, L.; Mabuni, C. A Critical Assessment of Chromium in the Environment. Crit. Rev. Environ. Sci. Technol. 1999, 29, 1-46. [CrossRef]

56. Pradhan, D.; Sukla, L.B.; Sawyer, M.; Rahman, P.K.S.M. Recent bioreduction of hexavalent chromium in wastewater treatment: A review. J. Ind. Eng. Chem. 2017, 55, 1-20. [CrossRef]

57. Bharagava, R.N.; Mishra, S. Hexavalent chromium reduction potential of Cellulosimicrobium sp. isolated from common effluent treatment plant of tannery industries. Ecotoxicol. Environ. Saf. 2018, 147, 102-109. [CrossRef]

58. Dermatas, D.; Mpouras, T.; Chrysochoou, M.; Panagiotakis, I.; Vatseris, C.; Linardos, N.; Theologou, E.; Boboti, N.; Xenidis, A.; Papassiopi, N.; et al. Origin and concentration profile of chromium in a Greek aquifer. J. Hazard. Mater. 2015, 281, 35-46. [CrossRef]

59. Tista, M.; Gager, M.; Gaisbauer, S.; Ullrich, B.; European Environment Agency. European Union Emission Inventory Report 1990-2017 under the UNECE Convention on Long-Range Transboundary Air Pollution (LRTAP); Publications Office of the European Union: Luxembourg, 2019; ISBN 978-92-9480-078-7.

60. Yan, B.; Chen, Z. Influence of $\mathrm{pH}$ on $\mathrm{Cr}(\mathrm{VI})$ reduction by organic reducing substances from sugarcane molasses. Appl. Water Sci. 2019, 9, 61. [CrossRef]

61. Wu, M.; Li, G.; Jiang, X.; Xiao, Q.; Niu, M.; Wang, Z.; Wang, Y. Non-biological reduction of Cr(VI) by reacting with humic acids composted from cattle manure. RSC Adv. 2017, 7, 26903-26911. [CrossRef]

62. Shanker, A.K. Chromium: Environmental Pollution, Health Effects and Mode of Action. In Encyclopedia of Environmental Health; Elsevier: Amsterdam, The Netherlands, 2019; pp. 624-633. ISBN 978-0-444-63952-3.

63. Albadarin, A.B.; Mangwandi, C.; Walker, G.M.; Allen, S.J.; Ahmad, M.N.M.; Khraisheh, M. Influence of solution chemistry on $\mathrm{Cr}(\mathrm{VI})$ reduction and complexation onto date-pits/tea-waste biomaterials. J. Environ. Manag. 2013, 114, 190-201. [CrossRef] [PubMed]

64. Bartlett, R.J. Chromium cycling in soils and water: Links, gaps, and methods. Environ. Health Perspect. 1991, 92, 8. [CrossRef]

65. Acosta-Rodríguez, I.; Cárdenas-González, J.F.; de Guadalupe Moctezuma-Zárate, M.; Martínez-Juárez, V.M. Removal of Hexavalent Chromium from Solutions and Contaminated Sites by Different Natural Biomasses. Appl. Bioremed.-Act. Passiv. Approaches 2013. [CrossRef] 
66. James, B.R. Chromium. In Encyclopedia of Water Science; CRC Press: Boca Raton, FL, USA, 2007; pp. $105-109$. ISBN 978-1-351-24981-2.

67. Jobby, R.; Jha, P.; Yadav, A.K.; Desai, N. Biosorption and biotransformation of hexavalent chromium [Cr(VI)]: A comprehensive review. Chemosphere 2018, 207, 255-266. [CrossRef]

68. Michalke, B. Metallomics: Analytical Techniques and Speciation Methods; Wiley-VCH: Weinheim, Germany, 2016; ISBN 978-3-527-69493-8.

69. Amy, G.; Yoon, J.; McNeill, L.; Banerjee, K. Chapter 2 Literature review. In Low-Level Hexavalent Chromium Treatment Options: Bench-Scale Evaluation; Brandhuber, P., Frey, M., McGuire, M.J., Chao, P., Seidel, C., Eds.; American Water Works Association Research Foundation: Denver, CO, USA, 2004; pp. 8-9.

70. Lichtfouse, E. Sustainable Agriculture Reviews; Springer Nature: London, UK, 2019; Volume 40, ISBN 978-3-030-33281-5.

71. American Public Health Association. Standard Methods for the Examination of Water and Wasterwater, 23rd ed.; Bridgewater, L.L., Baird, R.B., Eaton, A.D., Rice, E.W., American Public Health Association, American Water Works Association, Water Environment Federation, Eds.; American Public Health Association: Washington, DC, USA, 2017; ISBN 978-0-87553-287-5.

72. Gonzalez, A.R.; Ndung'u, K.; Flegal, A.R. Natural Occurrence of Hexavalent Chromium in the Aromas Red Sands Aquifer, California. Environ. Sci. Technol. 2005, 39, 5505-5511. [CrossRef] [PubMed]

73. Guerrero, M.M.L.; Alonso, E.V.; Pavón, J.M.C.; Cordero, M.T.S.; de Torres, A.G. On-line preconcentration using chelating and ion-exchange minicolumns for the speciation of chromium(iii) and chromium(vi) and their quantitative determination in natural waters by inductively coupled plasma mass spectrometry. J. Anal. At. Spectrom. 2012, 27, 682. [CrossRef]

74. Parks, J.L.; McNeill, L.; Frey, M.; Eaton, A.D.; Haghani, A.; Ramirez, L.; Edwards, M. Determination of total chromium in environmental water samples. Water Res. 2004, 38, 2827-2838. [CrossRef]

75. Yang, L.; Mester, Z.; Abranko, L.; Sturgeon, R.E. Determination of Total Chromium in Seawater by Isotope Dilution Sector Field ICPMS Using GC Sample Introduction. Anal. Chem. 2004, 76, 3510-3516. [CrossRef]

76. Malinski, T.; Fish, J.; Matusiewicz, H. Determining Ultratrace Metal Concentrations by Inductively Coupled Plasma Emission Spectrometry. J. Am. Water Work. Assoc. 1988, 80, 81-85. [CrossRef]

77. Rahman, G.M.M.; Kingston, H.M. 'Skip' Application of Speciated Isotope Dilution Mass Spectrometry To Evaluate Extraction Methods for Determining Mercury Speciation in Soils and Sediments. Anal. Chem. 2004, 76, 3548-3555. [CrossRef]

78. Wendelken, S.; Smith, G.; Munch, D.; Zaffiro, A.; Zimmerman, M. Method 218.7: Determination of Hexavalent Chromium in Drinking Water by Ion Chromatography with Post-Column Derivatization and UV-Visible Spectroscopic Detection; Version 1.0 November 2011; U.S. EPA Office of Water: Washington, DC, USA, 2011.

79. McNeill, L.; McLean, J.; Edwards, M.; Perks, J. Trace Level Hexavalent Chromium. Occurrence and Analysis; Project No. 4404; Water Research Foundation: Denver, CO, USA, 2013.

80. Martin, T.; Brockhoff, C.; Creed, J.; EMMC Methods Work Group. Method 200.7 Determination of Metals and Trace Elements in Water and Wastes by Inductively Coupled Plasma-Atomic Emission Spectrometry; Environmental Monitoring Systems Laboratory, Office of Research and Development, U.S. Environmental Protection Agency: Cincinnati, OH, USA, 1994.

81. Longbottom, J.E.; Martin, T.D.; Edgell, K.W.; Long, S.E.; Plantz, M.R.; Warden, B.E. Determination of Trace Elements in Water by Inductively Coupled Plasma-Mass Spectrometry: Collaborative Study. J. AOAC Int. 1994, 77, 1004-1023. [CrossRef]

82. Creed, J.; Martin, T.; O'Dell, J. Determination of Trace Elements by Stabilized Temperature Graphite Furnace Atomic Absorption; Environmental Monitoring Systems Laboratory Office of Reasearch and Development, USEPA: Cincinnati, OH, USA, 1994.

83. USEPA SW-846 Test Method 7199: Determination of Hexavalent Chromium in Drinking Water, Groundwater, and Industrial Wastewater Effluents by Ion Chromatography. Available online: https://www.epa.gov/hw-sw846/sw-846-test-method-7199-determination-hexavalent-chromiumdrinking-water-groundwater-and (accessed on 27 July 2020).

84. Lace, A.; Ryan, D.; Bowkett, M.; Cleary, J. Chromium Monitoring in Water by Colorimetry Using Optimised 1,5-Diphenylcarbazide Method. Int. J. Environ. Res. Public Health 2019, 16, 1803. [CrossRef] [PubMed]

85. USEPA Method 7197 Chromium, Hexavalent (Chelation/Extraction). Available online: https://www.epa.gov/ sites/production/files/2015-12/documents/7197.pdf (accessed on 27 July 2020). 
86. Hoshi, S.; Konuma, K.; Sugawara, K.; Uto, M.; Akatsuka, K. The simple and rapid spectrophotometric determination of trace chromium(VI) after preconcentration as its colored complex on chitin. Talanta 1998, 47, 659-663. [CrossRef]

87. EFSA Scientific Opinion on the safety of trivalent chromium as a nutrient added for nutritional purposes to foodstuffs for particular nutritional uses and foods intended for the general population (including food supplements). EFSA J. 2010, 8, 1882. [CrossRef]

88. Son, J.; Morris, J.; Park, K. Toenail Chromium Concentration and Metabolic Syndrome among Korean Adults. Int. J. Environ. Res. Public Health 2018, 15, 682. [CrossRef]

89. Nordberg, M.; Cherian, G.M. Chapter 9 Biological Response of Elements. In Essentials of Medical Geology; Revised ed.; Springer Science \& Business Media: Dordrecht, The Netherlands, 2013; pp. 195-213. ISBN 978-94-007-4375-5.

90. IARC CHROMIUM(VI) COMPOUNDS. Arsenic, Metals, Fibres and Dusts; IARC Monographs on the Evaluation of Carcinogenic Risks to Humans; International Agency for Research on Cancer: Lyon, France, 2012.

91. De Flora, S.; Serra, D.; Camoirano, A.; Zanacchi, P. Metabolic reduction of chromium, as related to its carcinogenic properties. Biol. Trace Elem. Res 1989, 21, 179-187. [CrossRef] [PubMed]

92. De Flora, S. Threshold mechanisms and site specificity in chromium(VI) carcinogenesis. Carcinogenesis 2000, 21, 533-541. [CrossRef] [PubMed]

93. De Flora, S.; Camoirano, A.; Micale, R.T.; La Maestra, S.; Savarino, V.; Zentilin, P.; Marabotto, E.; Suh, M.; Proctor, D.M. Reduction of hexavalent chromium by fasted and fed human gastric fluid. I. Chemical reduction and mitigation of mutagenicity. Toxicol. Appl. Pharmacol. 2016, 306, 113-119. [CrossRef]

94. Ray, R.R. Review article. Adverse hematological effects of hexavalent chromium: An overview. Interdiscip. Toxicol. 2016, 9, 55-65. [CrossRef]

95. Korallus, U.; Harzdorf, C.; Lewalter, J. Experimental bases for ascorbic acid therapy of poisoning by hexavalent chromium compounds. Int. Arch. Occup. Environ. Health 1984, 53, 247-256. [CrossRef]

96. Shrivastava, R.; Upreti, R.K.; Seth, P.K.; Chaturvedi, U.C. Effects of chromium on the immune system. FEMS Immunol. Med. Microbiol. 2002, 34, 1-7. [CrossRef] [PubMed]

97. Suh, M.; Wikoff, D.; Lipworth, L.; Goodman, M.; Fitch, S.; Mittal, L.; Ring, C.; Proctor, D. Hexavalent chromium and stomach cancer: A systematic review and meta-analysis. Crit. Rev. Toxicol. 2019, 49, 140-159. [CrossRef] [PubMed]

98. Saha, R.; Nandi, R.; Saha, B. Sources and toxicity of hexavalent chromium. J. Coord. Chem. 2011, 64, $1782-1806$. [CrossRef]

99. Fowler, J.F.J.; Kauffman, C.L.; Marks, J.G.J.; Proctor, D.M.; Fredrick, M.M.; Otani, J.M.; Finley, B.L.; Paustenbach, D.J.; Nethercott, J.R. An Environmental Hazard Assessment of Low-Level Dermal Exposure to Hexavalent Chromium in Solution among Chromium-Sensitized Volunteers. J. Occup. Environ. Med. 1999, 41, 150-160. [CrossRef]

100. Tiwari, A.K.; De Maio, M. Assessment of risk to human health due to intake of chromium in the groundwater of the Aosta Valley region, Italy. Hum. Ecol. Risk Assess. Int. J. 2017, 23, 1153-1163. [CrossRef]

101. Sun, H.; Brocato, J.; Costa, M. Oral Chromium Exposure and Toxicity. Curr. Environ. Health Rep. 2015, 2, 295-303. [CrossRef]

102. De Mandal, S.; Mathipi, V.; Muthukumaran, R.B.; Gurusubramanian, G.; Lalnunmawii, E.; Kumar, N.S. Amplicon sequencing and imputed metagenomic analysis of waste soil and sediment microbiome reveals unique bacterial communities and their functional attributes. Environ. Monit Assess 2019, 191, 778. [CrossRef]

103. Wise, S.S.; Wise, J.P. Chromium and genomic stability. Mutat. Res./Fundam. Mol. Mech. Mutagenesis 2012, 733, 78-82. [CrossRef]

104. Shi, X. Reduction of Chromium (vi) and Its Relationship to Carcinogenesis. J. Toxicol. Environ. Health Part B 1999, 2, 87-104. [CrossRef]

105. Messer, J.; Reynolds, M.; Stoddard, L.; Zhitkovich, A. Causes of DNA single-strand breaks during reduction of chromate by glutathione in vitro and in cells. Free Radic. Biol. Med. 2006, 40, 1981-1992. [CrossRef]

106. DeLoughery, Z.; Luczak, M.W.; Ortega-Atienza, S.; Zhitkovich, A. DNA double-strand breaks by Cr(VI) are targeted to euchromatin and cause ATR-dependent phosphorylation of histone H2AX and its ubiquitination. Toxicol. Sci. 2015, 143, 54-63. [CrossRef] [PubMed] 
107. Li, M.-H.; Gao, X.-Y.; Li, C.; Yang, C.-L.; Fu, C.-A.; Liu, J.; Wang, R.; Chen, L.-X.; Lin, J.-Q.; Liu, X.-M.; et al. Isolation and Identification of Chromium Reducing Bacillus Cereus Species from Chromium-Contaminated Soil for the Biological Detoxification of Chromium. Int. J. Environ. Res. Public Health 2020, 17, 2118. [CrossRef]

108. Qian, J.; Wei, L.; Liu, R.; Jiang, F.; Hao, X.; Chen, G.-H. An Exploratory Study on the Pathways of Cr (VI) Reduction in Sulfate-reducing Up-flow Anaerobic Sludge Bed (UASB) Reactor. Sci. Rep. 2016, 6, 23694. [CrossRef] [PubMed]

109. Focardi, S.; Pepi, M.; Focardi, E.S. Microbial Reduction of Hexavalent Chromium as a Mechanism of Detoxification and Possible Bioremediation Applications. In Biodegradation - Life of Science; Chamy, R., Ed.; InTech: London, UK, 2013; ISBN 978-953-51-1154-2.

110. Stylianou, S.; Simeonidis, K.; Mitrakas, M.; Zouboulis, A.; Ernst, M.; Katsoyiannis, I.A. Reductive precipitation and removal of $\mathrm{Cr}(\mathrm{VI})$ from groundwaters by pipe flocculation-microfiltration. Environ. Sci. Pollut. Res. 2018, 25, 12256-12262. [CrossRef]

111. Shi, L.; Zhang, X.; Chen, Z. Removal of Chromium (VI) from wastewater using bentonite-supported nanoscale zero-valent iron. Water Res. 2011, 45, 886-892. [CrossRef] [PubMed]

112. Ahamed, M.I.N.; Rajeshkumar, S.; Ragul, V.; Anand, S.; Kaviyarasu, K. Chromium remediation and toxicity assessment of nano zerovalent iron against contaminated lake water sample (Puliyanthangal Lake, Tamilnadu, India). S. Afr. J. Chem. Eng. 2018, 25, 128-132. [CrossRef]

113. Fu, R.; Yang, Y.; Xu, Z.; Zhang, X.; Guo, X.; Bi, D. The removal of chromium (VI) and lead (II) from groundwater using sepiolite-supported nanoscale zero-valent iron (S-NZVI). Chemosphere 2015, 138, 726-734. [CrossRef]

114. Kononova, O.N.; Bryuzgina, G.L.; Apchitaeva, O.V.; Kononov, Y.S. Ion exchange recovery of chromium (VI) and manganese (II) from aqueous solutions. Arab. J. Chem. 2019, 12, 2713-2720. [CrossRef]

115. Zhang, B.; Luan, L.; Gao, R.; Li, F.; Li, Y.; Wu, T. Rapid and effective removal of Cr(VI) from aqueous solution using exfoliated LDH nanosheets. Colloids Surf. A Physicochem. Eng. Asp. 2017, 520, 399-408. [CrossRef]

116. Kan, C.-C.; Ibe, A.H.; Rivera, K.K.P.; Arazo, R.O.; de Luna, M.D.G. Hexavalent chromium removal from aqueous solution by adsorbents synthesized from groundwater treatment residuals. Sustain. Environ. Res. 2017, 27, 163-171. [CrossRef]

117. Choppala, G.; Kunhikrishnan, A.; Seshadri, B.; Park, J.H.; Bush, R.; Bolan, N. Comparative sorption of chromium species as influenced by $\mathrm{pH}$, surface charge and organic matter content in contaminated soils. J. Geochem. Explor. 2018, 184, 255-260. [CrossRef]

118. Tamura, H.; Tanaka, A.; Mita, K.; Furuichi, R. Surface Hydroxyl Site Densities on Metal Oxides as a Measure for the Ion-Exchange Capacity. J. Colloid Interface Sci. 1999, 209, 225-231. [CrossRef] [PubMed]

119. Yadav, S.; Srivastava, V.; Banerjee, S.; Weng, C.-H.; Sharma, Y.C. Adsorption characteristics of modified sand for the removal of hexavalent chromium ions from aqueous solutions: Kinetic, thermodynamic and equilibrium studies. CATENA 2013, 100, 120-127. [CrossRef]

120. Anastopoulos, I.; Anagnostopoulos, V.A.; Bhatnagar, A.; Mitropoulos, A.C.; Kyzas, G.Z. A review for chromium removal by carbon nanotubes. Chem. Ecol. 2017, 33, 572-588. [CrossRef]

121. Liu, H.-M.; Zhao, X.-J.; Zhu, Y.-Q.; Yan, H. DFT study on MgAl-layered double hydroxides with different interlayer anions: Structure, anion exchange, host-guest interaction and basic sites. Phys. Chem. Chem. Phys. 2020, 22, 2521-2529. [CrossRef]

122. Xia, S.; Song, Z.; Jeyakumar, P.; Shaheen, S.M.; Rinklebe, J.; Ok, Y.S.; Bolan, N.; Wang, H. A critical review on bioremediation technologies for $\mathrm{Cr}(\mathrm{VI})$-contaminated soils and wastewater. Crit. Rev. Environ. Sci. Technol. 2019, 49, 1027-1078. [CrossRef]

123. Enniya, I.; Rghioui, L.; Jourani, A. Adsorption of hexavalent chromium in aqueous solution on activated carbon prepared from apple peels. Sustain. Chem. Pharm. 2018, 7, 9-16. [CrossRef]

124. Guo, H.; Bi, C.; Zeng, C.; Ma, W.; Yan, L.; Li, K.; Wei, K. Camellia oleifera seed shell carbon as an efficient renewable bio-adsorbent for the adsorption removal of hexavalent chromium and methylene blue from aqueous solution. J. Mol. Liq. 2018, 249, 629-636. [CrossRef]

125. Plummer, S.; Gorman, C.; Henrie, T.; Shimabuku, K.; Thompson, R.; Seidel, C. Optimization of strong-base anion exchange O\&M costs for hexavalent chromium treatment. Water Res. 2018, 139, 420-433. [CrossRef]

126. Korak, J.A.; Huggins, R.; Arias-Paic, M. Regeneration of pilot-scale ion exchange columns for hexavalent chromium removal. Water Res. 2017, 118, 141-151. [CrossRef] [PubMed] 
127. Golder, A.K.; Chanda, A.K.; Samanta, A.N.; Ray, S. Removal of Cr(VI) from Aqueous Solution: Electrocoagulation vs Chemical Coagulation. Sep. Sci. Technol. 2007, 42, 2177-2193. [CrossRef]

128. El-Taweel, Y.A.; Nassef, E.M.; Elkheriany, I.; Sayed, D. Removal of Cr(VI) ions from waste water by electrocoagulation using iron electrode. Egypt. J. Pet. 2015, 24, 183-192. [CrossRef]

129. Al-Qodah, Z.; Al-Shannag, M. Heavy metal ions removal from wastewater using electrocoagulation processes: A comprehensive review. Sep. Sci. Technol. 2017, 1-28. [CrossRef]

130. Zewail, T.M.; Yousef, N.S. Chromium ions (Cr6+ \& $\mathrm{Cr} 3+)$ removal from synthetic wastewater by electrocoagulation using vertical expanded Fe anode. J. Electroanal. Chem. 2014, 735, 123-128. [CrossRef]

131. Sharma, D.; Chaudhari, P.K.; Prajapati, A.K. Removal of chromium (VI) and lead from electroplating effluent using electrocoagulation. Sep. Sci. Technol. 2020, 55, 321-331. [CrossRef]

132. Genawi, N.M.; Ibrahim, M.H.; El-Naas, M.H.; Alshaik, A.E. Chromium Removal from Tannery Wastewater by Electrocoagulation: Optimization and Sludge Characterization. Water 2020, 12, 1374. [CrossRef]

133. Dermentzis, K.; Christophoridis, A.; Valsamidou, E.; Lazaridou, A.; Kokkinos, N. Removal of hexavalent chromium from electroplating wastewater by electrocoagulation with iron electrodes. Glob. NEST J. 2011, 13, 412-418. [CrossRef]

134. Majone, M.; Verdini, R.; Aulenta, F.; Rossetti, S.; Tandoi, V.; Kalogerakis, N.; Agathos, S.; Puig, S.; Zanaroli, G.; Fava, F. In situ groundwater and sediment bioremediation: Barriers and perspectives at European contaminated sites. New Biotechnol. 2015, 32, 133-146. [CrossRef]

135. Mtimunye, P.J.; Lutsinge, T.B.; Molokwane, P.E.; Chirwa, E.M.N. Cr(vi) remediation in groundwater aquifer media using natural organic matter as carbon source. Chem. Eng. Trans. 2017, 61, 1831-1836. [CrossRef]

136. Aslam, F.; Yasmin, A.; Sohail, S. Bioaccumulation of lead, chromium, and nickel by bacteria from three different genera isolated from industrial effluent. Int. Microbiol. 2020, 23, 253-261. [CrossRef]

137. Elahi, A.; Rehman, A. Comparative behavior of two gram positive Cr6+ resistant bacterial strains Bacillus aerius S1 and Brevibacterium iodinum S2 under hexavalent chromium stress. Biotechnol. Rep. 2019, 21 , e00307. [CrossRef] [PubMed]

138. Gong, K.; Guo, S.; Zhao, Y.; Hu, Q.; Liu, H.; Sun, D.; Li, M.; Qiu, B.; Guo, Z. Bacteria cell templated porous polyaniline facilitated detoxification and recovery of hexavalent chromium. J. Mater. Chem. A 2018, 6, 16824-16832. [CrossRef]

139. Rajeswari, V.; Janaki, V.; Shanthi, K.; Kamala-Kannan, S. Adsorption and subsequent detoxification of hexavalent chromium in aqueous solution using polypyrrole-bacterial extracellular polysaccharide nanocomposite. Environ. Prog. Sustain. Energy 2016, 35, 1293-1297. [CrossRef]

140. Alam, M.Z.; Ahmad, S. Chromium Removal through Biosorption and Bioaccumulation by Bacteria from Tannery Effluents Contaminated Soil. CLEAN-Soil Air Water 2011, 39, 226-237. [CrossRef]

141. Shamim, S. Biosorption of Heavy Metals. In Biosorption; Derco, J., Vrana, B., Eds.; BoD-Books on Demand: London, UK, 2018; ISBN 978-1-78923-472-5.

142. Asri, M.; Elabed, A.; Tirry, N.; Kouchou, A.; Ibnsouda Koraichi, S.; El Ghachtouli, N.; Elabed, S. Correlation between cell surface physicochemical properties of bacterial strains and their chromium removal potential. J. Adhes. Sci. Technol. 2017, 31, 2730-2740. [CrossRef]

143. Beveridge, T.J.; Murray, R.G. Sites of metal deposition in the cell wall of Bacillus subtilis. J. Bacteriol. 1980, 141, 876-887. [CrossRef]

144. Karimpour, M.; Ashrafi, S.D.; Taghavi, K.; Mojtahedi, A.; Roohbakhsh, E.; Naghipour, D. Adsorption of cadmium and lead onto live and dead cell mass of Pseudomonas aeruginosa: A dataset. Data Brief 2018, 18, 1185-1192. [CrossRef]

145. Igiri, B.E.; Okoduwa, S.I.R.; Idoko, G.O.; Akabuogu, E.P.; Adeyi, A.O.; Ejiogu, I.K. Toxicity and Bioremediation of Heavy Metals Contaminated Ecosystem from Tannery Wastewater: A Review. J. Toxicol. 2018, 2018. [CrossRef]

146. Gutiérrez-Corona, J.F.; Romo-Rodríguez, P.; Santos-Escobar, F.; Espino-Saldaña, A.E.; Hernández-Escoto, H. Microbial interactions with chromium: Basic biological processes and applications in environmental biotechnology. World J. Microbiol. Biotechnol. 2016, 32, 191. [CrossRef]

147. Volesky, B.; Holan, Z.R. Biosorption of Heavy Metals. Available online: https://pubs.acs.org/doi/pdf/10.1021/ bp00033a001 (accessed on 23 June 2020).

148. Srinath, T.; Verma, T.; Ramteke, P.W.; Garg, S.K. Chromium (VI) biosorption and bioaccumulation by chromate resistant bacteria. Chemosphere 2002, 48, 427-435. [CrossRef] 
149. Raman, N.M.; Asokan, S.; Shobana Sundari, N.; Ramasamy, S. Bioremediation of chromium(VI) by Stenotrophomonas maltophilia isolated from tannery effluent. Int. J. Environ. Sci. Technol. 2018, 15, 207-216. [CrossRef]

150. Xu, R.; Wu, K.; Han, H.; Ling, Z.; Chen, Z.; Liu, P.; Xiong, J.; Tian, F.; Zafar, Y.; Malik, K.; et al. Co-expression of YieF and PhoN in Deinococcus radiodurans R1 improves uranium bioprecipitation by reducing chromium interference. Chemosphere 2018, 211, 1156-1165. [CrossRef] [PubMed]

151. Xiao, W.; Ye, X.; Yang, X.; Zhu, Z.; Sun, C.; Zhang, Q.; Xu, P. Isolation and characterization of chromium(VI)-reducing Bacillus sp. FY1 and Arthrobacter sp. WZ2 and their bioremediation potential. Bioremediation J. 2017, 21, 100-108. [CrossRef]

152. Mohamed, M.S.M.; El-Arabi, N.I.; El-Hussein, A.; El-Maaty, S.A.; Abdelhadi, A.A. Reduction of chromium-VI by chromium-resistant Escherichia coli FACU: A prospective bacterium for bioremediation. Folia Microbiol. 2020. [CrossRef]

153. Wani, P.A.; Wahid, S.; Khan, M.S.A.; Rafi, N.; Wahid, N. Investigation of the role of chromium reductase for $\mathrm{Cr}$ (VI) reduction by Pseudomonas species isolated from $\mathrm{Cr}$ (VI) contaminated effluent. Biotechnol. Res. Innov. 2019, 3, 38-46. [CrossRef]

154. Gang, H.; Xiao, C.; Xiao, Y.; Yan, W.; Bai, R.; Ding, R.; Yang, Z.; Zhao, F. Proteomic analysis of the reduction and resistance mechanisms of Shewanella oneidensis MR-1 under long-term hexavalent chromium stress. Environ. Int. 2019, 127, 94-102. [CrossRef]

155. Yan, J.; Ye, W.; Jian, Z.; Xie, J.; Zhong, K.; Wang, S.; Hu, H.; Chen, Z.; Wen, H.; Zhang, H. Enhanced sulfate and metal removal by reduced graphene oxide self-assembled Enterococcus avium sulfate-reducing bacteria particles. Bioresour. Technol. 2018, 266, 447-453. [CrossRef]

156. Opperman, D.J.; Piater, L.A.; Heerden, E. van A Novel Chromate Reductase from Thermus scotoductus SA-01 Related to Old Yellow Enzyme. J. Bacteriol. 2008, 190, 3076-3082. [CrossRef]

157. Tandon, S.; Jha, M.; Dudhwadkar, S. Study on Ochrobactrum pseudintermedium ADV31 for the removal of hexavalent chromium through different immobilization techniques. SN Appl. Sci. 2020, 2, 296. [CrossRef]

158. Zhao, J.; Al, T.; Chapman, S.W.; Parker, B.L.; Mishkin, K.R.; Cutt, D.; Wilkin, R.T. Determination of Cr(III) solids formed by reduction of $\mathrm{Cr}(\mathrm{VI})$ in a contaminated fractured bedrock aquifer: Evidence for natural attenuation of $\mathrm{Cr}(\mathrm{VI})$. Chem. Geol. 2017, 474, 1-8. [CrossRef]

159. Wen, C.; Sheng, H.; Ren, L.; Dong, Y.; Dong, J. Study on the removal of hexavalent chromium from contaminated groundwater using emulsified vegetable oil. Process Saf. Environ. Prot. 2017, 109, 599-608. [CrossRef]

160. Zhang, B.; Wang, Z.; Shi, J.; Dong, H. Sulfur-based mixotrophic bio-reduction for efficient removal of chromium (VI) in groundwater. Geochim. Cosmochim. Acta 2020, 268, 296-309. [CrossRef]

161. Zhao, Y.; Hsieh, H.-S.; Wang, M.; Jafvert, C.T. Light-independent redox reactions of graphene oxide in water: Electron transfer from NADH through graphene oxide to molecular oxygen, producing reactive oxygen species. Carbon 2017, 123, 216-222. [CrossRef]

162. Liu, X.; Wu, G.; Zhang, Y.; Wu, D.; Li, X.; Liu, P. Chromate Reductase YieF from Escherichia coli Enhances Hexavalent Chromium Resistance of Human HepG2 Cells. Int. J. Mol. Sci. 2015, 16, 11892-11902. [CrossRef] [PubMed]

163. Eswaramoorthy, S.; Poulain, S.; Hienerwadel, R.; Bremond, N.; Sylvester, M.D.; Zhang, Y.-B.; Berthomieu, C.; Van Der Lelie, D.; Matin, A. Crystal Structure of ChrR-A Quinone Reductase with the Capacity to Reduce Chromate. PLoS ONE 2012, 7. [CrossRef] [PubMed]

164. Ackerley, D.F.; Barak, Y.; Lynch, S.V.; Curtin, J.; Matin, A. Effect of Chromate Stress on Escherichia coli K-12. J. Bacteriol. 2006, 188, 3371-3381. [CrossRef] [PubMed]

165. Ramírez-Díaz, M.I.; Díaz-Pérez, C.; Vargas, E.; Riveros-Rosas, H.; Campos-García, J.; Cervantes, C. Mechanisms of bacterial resistance to chromium compounds. Biometals 2008, 21, 321-332. [CrossRef]

166. Ma, L.; Chen, N.; Feng, C.; Li, M.; Gao, Y.; Hu, Y. Coupling enhancement of Chromium(VI) bioreduction in groundwater by phosphorus minerals. Chemosphere 2020, 240, 124896. [CrossRef]

167. EPA. Chapter X In-Situ Groundwater Bioremediation. In How to Evaluate Alternative Cleanup Technologies for Underground Storage Tank Sites a Guide for Corrective Action Plan Reviewers. Available online: https: //www.epa.gov/sites/production/files/2014-03/documents/tum_ch10.pdf (accessed on 27 July 2020). 
168. Linkov, I.; Varghese, A.; Jamil, S.; Seager, T.P.; Kiker, G.; Bridges, T. Multi-Criteria Decision Analysis: A Framework for Structuring Remedial Decisions at Contaminated Sites. In Comparative Risk Assessment and Environmental Decision Making; Linkov, I., Ramadan, A.B., Eds.; Nato Science Series: IV: Earth and Environmental Sciences; Kluwer Academic Publishers: Dordrecht, The Netherlands, 2005; Volume 38, pp. 15-54. ISBN 978-1-4020-1895-4.

169. Crini, G.; Lichtfouse, E. Green Adsorbents for Pollutant Removal: Innovative Materials; Springer: Berlin/Heidelberg, Germany, 2018; ISBN 978-3-319-92162-4.

170. GracePavithra, K.; Jaikumar, V.; Kumar, P.S.; SundarRajan, P. A review on cleaner strategies for chromium industrial wastewater: Present research and future perspective. J. Clean. Prod. 2019, 228, 580-593. [CrossRef]

171. Bazrafshan, E.; Mahvi, A.H.; Naseri, S.; Mesdaghinia, A.R. Performance Evaluation of Electrocoagulation Process for Removal of Chromium (VI) from Synthetic Chromium Solutions Using Iron and Aluminum Electrodes. Turk. J. Eng. Environ. Sci. 2008, 32, 59-66.

172. Ihsanullah; Al-Khaldi, F.A.; Abu-Sharkh, B.; Abulkibash, A.M.; Qureshi, M.I.; Laoui, T.; Atieh, M.A. Effect of acid modification on adsorption of hexavalent chromium $(\mathrm{Cr}(\mathrm{VI}))$ from aqueous solution by activated carbon and carbon nanotubes. Desalin. Water Treat. 2016, 57, 7232-7244. [CrossRef]

(C) 2020 by the authors. Licensee MDPI, Basel, Switzerland. This article is an open access article distributed under the terms and conditions of the Creative Commons Attribution (CC BY) license (http://creativecommons.org/licenses/by/4.0/). 